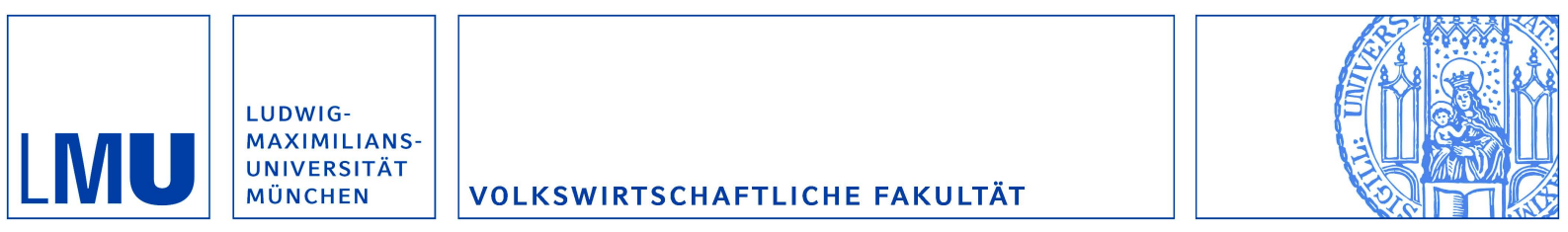

Gratz, Linda:

Economic Analysis of Pay-for-delay Settlements and Their Legal Ruling

Munich Discussion Paper No. 2012-6

Department of Economics

University of Munich

Volkswirtschaftliche Fakultät

Ludwig-Maximilians-Universität München

Online at https://doi.org/10.5282/ubm/epub. 12734 


\title{
Economic Analysis of Pay-for-delay Settlements and Their Legal Ruling ${ }^{\star}$
}

\author{
LINDA GRATZ
}

\begin{abstract}
In this paper, we ask whether courts should continue to rule settlements in the context of pharmaceutical claims per se legal, when these settlements comprise payments from originator to generic companies, potentially delaying generic entry compared to the underlying litigation. Within a theoretical framework we compare consumer welfare under the rule of per se legality with that under alternative standards. We find that the rule of per se legality induces maximal collusion among settling companies. In comparison, the rule of per se illegality entirely prevents collusion and the rule of reason induces limited collusion when antitrust enforcement is subject to error. Contrary to intuition, limited collusion can be welfare enhancing as it increases companies' expected settlement profits and thus fosters generic entry. Generic companies obtain additional incentives to challenge probabilistic patents, which potentially leads to overall increased competition. We further show that generic entry is fostered more effectively by inducing limited collusion than by rewarding first generic entrants with an exclusivity right.
\end{abstract}

Keywords: antitrust and intellectual property law, patent settlements, collusion, per se rule, rule of reason, Hatch-Waxman Act

JEL classification: I18, K40, L40, O34

\footnotetext{
${ }^{\star}$ I wish to thank Klaus M. Schmidt as well as Florian Englmaier, Bernhard Ganglmair, John M. Golden, Stuart Graham, C. Scott Hemphill, Fabian Herweg and Johannes Maier for helpful conversations. I am also thankful to participants at the Annual Conference of the EPIP Association 2010 in Maastricht, at the Annual Conference of EALE 2010 in Paris, at the IMPRS-CI/ETH Workshop 2010 in Wildbad-Kreuth, at CISS 2010 in Turunc, and at seminars of the Columbia University, the IMPRS-CI and the University of Munich for useful comments and suggestions.

${ }^{\diamond}$ Linda Gratz, International Max-Planck Research School for Competition and Innovation (IMPRSCI), Marstallplatz 1, 80539 München, Germany. E-mail: l.gratz@yahoo.de.
} 


\section{Introduction}

The generic company Barr Pharmaceuticals recently received $\$ 398.1$ million from the originator company Bayer AG for giving up an invalidity claim and stopping the production of a generic version of Bayer's antibiotic Cipro until the end of patent exclusivity. The question arises why originator companies would want to settle on such unfavorable terms. If they held ironclad patents, they could exclude their competitors through litigation, merely paying litigation costs. There is strong indication that in cases like this, in which the patent holders make large payments to the alleged infringers, the patents at issue are in fact not ironclad but probabilistic, meaning with positive probability the patents would be declared invalid or non-infringed by court. In these cases, the expected generic entry date under litigation lies prior to the end of patent exclusivity, which implies that originator and generic companies can use settlements to delay generic entry compared to litigation. Large payments from originator to generic companies are then rationalized as a reimbursement for the entry delay and as a share in the surplus generated through the entry delay.

So, originator and generic companies potentially restrict competition through payfor-delay settlements, delaying generic entry compared to the litigation alternative. ${ }^{1}$ Under antitrust law, agreements that restrict competition are per se illegal as they lead to static inefficiency. The present legal standard in the US, however, stipulates that pay-for-delay settlements are per se legal. Since the originator companies still hold valid patents at the time of settlement, it has been argued that the application of antitrust rules would be inadmissible. In Bayer vs. Barr, for instance, the District Court reasoned that any anticompetitive effects were "within the exclusionary zone of the patent", and thus could not be redressed by antitrust law. So currently, US courts act on the presumption that granted patents are ironclad as long as there has not been a declaratory judgment to the contrary. In light of the probabilistic nature of the patents at issue the question arises, whether this is desirable. Should courts continue to rule pay-for-delay settlements per se legal or apply an alternative rule, either the rule of per se illegality or the rule of reason? Under both these alternative rules antitrust law would be applied. Under the rule of per se illegality courts would rule settlements that comprise value transfers from originator to generic companies per se illegal. In contrast, under the rule of reason courts would inquire into the market conditions more comprehensively, balancing pro- against anticompetitive settlement

\footnotetext{
${ }^{1}$ For a survey on pay-for-delay settlements see Hemphill (2009).
} 
effects. The question, which rule toward pay-for-delay settlements yields the highest consumer welfare, is important also in light of the fact that in the EU regulation of pay-for-delay settlements is still in its infancy. ${ }^{2}$ We try to answer this question within a theoretical analysis.

In our framework, originator companies have entered a marketplace for pharmaceuticals with patented products. Because the patents are probabilistic, generic companies contemplate market entry with generic products prior to the patents' expiration. In case of generic entry patent disputes are triggered, resulting in either litigations or settlement agreements. Both parties view settlements superior to litigations as the settlement profits they can obtain are at least as high as the expected litigation profits. When settling, the companies decide on generic entry dates and if permitted on value transfers. Settlements are ruled by courts. We apply the consumer welfare standard to assess which rule is favorable in practice.

Since under the rule of per se legality value transfers within settlements are legal, companies can maximize their joint profits by colluding maximally. That is, they can maximize their joint profits by delaying generic entry until the end of patent duration (as in the case of Bayer vs. Barr). Under the rule of per se illegality value transfers from originator to generic companies within settlements are illegal, so that originator companies cannot compensate generic companies for a delay in entry compared to litigation. Thus, settling companies agree upon entry terms that would in expectation result under litigation and are entirely prevented from colluding. Under the rule of reason settling companies are allowed to transfer values but courts prohibit those settlements that they regard anticompetitive. We take into consideration that under the rule of reason courts might make errors when evaluating settlements. Our analysis reveals that imprecise evaluations induce settling companies to collude. The reason is that the likelihood that anticompetitive settlements get approved increases when courts' evaluations become less precise. It then pays more for the companies to choose particularly late generic entry dates. Thus, the more antitrust enforcement is subject to error under the rule of reason, the more settling companies collude.

Intuitively, these results speak for an amendment toward the rule of per se illegality as only under this rule collusion can entirely be prevented. However, as a main result we

\footnotetext{
${ }^{2}$ Since 2008 the European Commission (EC) publishes monitoring reports on pay-for-delay settlements (see EC 2008, 2009, 2010). Since 2009, it opened first formal antitrust investigations in a number of pay-for-delay settlements for suspected breaches of Articles 101 and 102 of the Treaty on the Functioning of the European Union (TFEU) (see MEMO/09/322, IP/10/8, IP/11/511 and IP/11/1228). Generally, it advocates restrictions on pay-for-delay settlements.
} 
show that, contrary to intuition, collusion can be beneficial. We presume that generic companies' incentives to challenge probabilistic patents are restricted due to the high additional costs that challenge processes necessitate. The possibility of collusion therefore provides generic companies additional incentives to challenge probabilistic patents as it increases their expected settlement profits. Additional settlement agreements result where otherwise the holders of probabilistic patents would remain monopolists. As long as collusion under the additional settlements is limited, competition increases, affecting consumer welfare positively.

Under the rule of per se legality settling companies collude maximally, so that consumer welfare does not increase due to the additional patent challenges. Therefore, the rule of per se legality yields the lowest consumer welfare compared to the alternative rules. The rule of reason has the paradoxical advantage over the rule of per se illegality that it induces limited collusion, thereby enhancing generic companies' incentives to challenge probabilistic patents. We show that the rule of reason outperforms the rule of per se illegality when generic companies' incentives to enter are low. In that case, the benefit adhered to collusion, i.e., the benefit of additional settlement agreements, outweighs the cost adhered to collusion, i.e., the cost that under each settlement competition is restrained.

We make a critical assessment of this first result by asking whether there exist alternative incentive mechanism to foster generic entry that are more effective than permitting collusion between originator and generic companies. The US Hatch-Waxman Act of 1984 potentially provides such an alternative incentive mechanism. It stipulates that generic companies first challenging a patent obtain 180 days of marketing exclusivity during which no subsequent generic company may enter. As a second result we find that this prominent incentive device does in fact not have the desired incentive effect and is detrimental to consumer welfare.

In our welfare analysis we only consider effects on static efficiency, resulting from competition among existing products. We therefore discuss whether a welfare analysis requires to also consider dynamic efficiency, resulting from the creation of new products. Static and dynamic efficiency might go hand in hand. Nevertheless, under the consideration of dynamic efficiency collusion could have the additional beneficial effect that it also increases originator companies' expected settlement profits and thus their incentives to innovate. But the possibility of collusion could as well impair dynamic efficiency as it has the effect that originator companies are able to obtain relatively high profits with weak inventions, which might negatively bias their investment decisions. 
In the previous literature the vast majority of researchers also argues for an amendment of the current legal approach. Willig and Bigelow (2004) and Addanki and Daskin (2008) argue in favor of the rule reason because it allows for payments from originator to generic companies and such payments could for various reasons be necessary to facilitate procompetitive settlements. ${ }^{3}$ However, they do not take into account that under the rule of reason courts might make errors in their evaluations and approve anticompetitive settlements. As briefly mentioned by Salinger, Ippolito, and Schrag (2007), when there exists the chance that anticompetitive settlements get approved, this might induce companies to conclude not pro- but anticompetitive settlements. ${ }^{4}$ Our analysis accounts for the fact that antitrust evaluations under the rule of reason might be subject to error. To the best of our knowledge this is the first formal analysis in which the welfare effects of the different legal rulings toward pay-for-delay settlements are compared.

The structure of the paper is as follows. In Section 2, we outline the model. Section 3 analyzes to what extent settling companies collude and how high generic companies' incentives to contest probabilistic patents are under the different rules. In Section 4, we determine how the legal ruling affects welfare. Section 5 assesses the welfare effects of the Hatch-Waxman Act provisions. Results are discussed in Section 6 and Section 7 concludes.

\section{The Model}

We analyze a marketplace for pharmaceuticals, which originator companies (denoted $O)$ have entered with patented products. For each patented product there are two companies sequentially seeking market entry with generic products prior to the patents' expiration. ${ }^{5}$ At time $t=0$ the first generic companies (denoted $G_{1}$ ) decide on entry, and at time $t=\lambda$, with $\lambda \in(0,1]$, the second generic companies (denoted $G_{2}$ ) decide

\footnotetext{
${ }^{3}$ Other authors arguing that the majority of pay-for-delay settlements should be procompetitive, include Blair and Cotter (2002), Crane (2002), Langenfeld and Li (2003) and Schildkraut (2004).

${ }^{4}$ Bulow (2003), Hemphill (2006, 2009), Hovenkamp, Janis and Lemley (2003), Leffler and Leffler (2004), Lemley and Shapiro (2005), O'Rourke and Brodley (2003), and Shapiro (2003) also argue that pay-for-delay settlements should create a presumption of anticompetitive behavior.

${ }^{5}$ We consider the case of two generic companies sequentially seeking market entry because in Section 5 we want to investigate the welfare effects of the Hatch-Waxman Act provisions, which stipulate that generic companies first entering award an exclusivity right which delays subsequent generics' entry. Further, the FTC (2002) reports that at most two generic companies challenged probabilistic patents in the past. This number is lower than the number of generic companies seeking market entry after patent expiration because a challenge process necessitates additional costs, amounting to $\$ 1$ million. Our results would also hold for simultaneous entry when $\lambda=0$. We do not consider this case explicitly for the sake of brevity.
} 
on entry. Patent exclusivity ends at time $t=1$.

When entering, the generic companies trigger patent disputes. They incur a fixed cost $f_{g}$, which consists of proving bioequivalence and of bringing forward a detailed description of why they believe that the originator's patent is invalid or non-infringed. These fixed costs are not precisely known by other companies. The patent disputes result in either litigations or settlement agreements. As will be shown in Section 3, both parties view settlements as superior to litigations because the profits they can obtain by settling are at least as high as expected litigation profits. ${ }^{6}$ However, the expected outcome of litigation is the basis for negotiation in the settlement talks. If negotiations break down and no bargain can be reached, the expected outcome of litigation is the value the players receive. When settling, the companies decide on generic entry dates and if permitted on value transfers. ${ }^{7}$

Nature determines the probabilities with which courts would declare the patents valid under litigations. These probabilities, denoted by $\gamma$, are common knowledge to originator and generic companies, and uniformly distributed between 0 and 1, i.e., $\gamma \sim U[0,1] .{ }^{8}$ The probability of patent validity reflects the strength of the patents. When $\gamma$ equals zero a patent is invalid, and when $\gamma$ equals one a patent is ironclad. ${ }^{9}$

Under litigations generic entry would be uncertain. With probability $\gamma$ courts would declare the patents valid and generic entry would occur at the end of patent duration, i.e., at $t=1$, whereas with probability $1-\gamma$ courts would declare the patents invalid and generic entry would occur immediately $\left(G_{1}\right.$ would enter at $t=0$ and $G_{2}$ would enter at $t=\lambda) \cdot{ }^{10}$ By contrast, under settlements the companies can agree on any certain future entry date $t_{g_{1}} \in[0,1]$ and $t_{g_{2}} \in[\lambda, 1]$. In order to be able to compare the uncertain entry dates under litigations with the certain entry dates under settlements, we make use of a continuous time model without discounting. We compute probabilistic weightings of the uncertain entry dates under litigations, which

\footnotetext{
${ }^{6}$ Further reasons why companies prefer settlements can be that settlements costs are lower than litigation costs and that settlements provide legal certainty (see appendices A3 and A4).

${ }^{7}$ Likewise, settling parties could restrict competition by agreeing upon per-unit royalty rates, a fixed price, quantity-restrictions, territory dispartments or mergers. We assume that these other settlement forms are regulated such that none of them yields higher returns than ongoing litigation.

${ }^{8}$ In Appendix A3, we deal with cases in which the companies misperceive $\gamma$.

${ }^{9}$ In practice, expected settlement profits also depend on the commercial value of the patents. Further, patents might be strong but easy to 'invent around'. The results we obtain regarding patents of low strength $\gamma$ also hold true for patents of high commercial value and patents non-infringed with probability $\gamma$.

${ }^{10} \mathrm{We}$ assume that a dispute is triggered and resolved at the same point in time. If we denoted two separate points in time, both parties' reference entry dates would postpone, and with it the entry dates under the rule of per se illegality and under the rule of reason. The welfare implications would not change.
} 
we will refer to as expected entry dates under litigations. $G_{1}$ 's expected entry date under litigation is $t_{g_{1}}^{l}=\gamma \cdot 1+(1-\gamma) \cdot 0=\gamma$ since under litigation $G_{1}$ enters with probability $\gamma$ at time $t=1$ and with probability $(1-\gamma)$ at time $t=0 .{ }^{11}$ For settling companies as well as consumers this entry date is of equal value as a $\gamma$ percent chance of $G_{1}$ entering at the end of patent duration (at $t=1$ ) and a $1-\gamma$ percent chance of $G_{1}$ entering immediately (at $t=0$ ). ${ }^{12}$ Accordingly, $G_{2}$ 's expected entry date under litigation is $t_{g_{2}}^{l}=\gamma \cdot 1+(1-\gamma) \cdot \lambda$ as under litigation $G_{2}$ enters with probability $\gamma$ at time $t=1$ and with probability $1-\gamma$ at time $t=\lambda$.

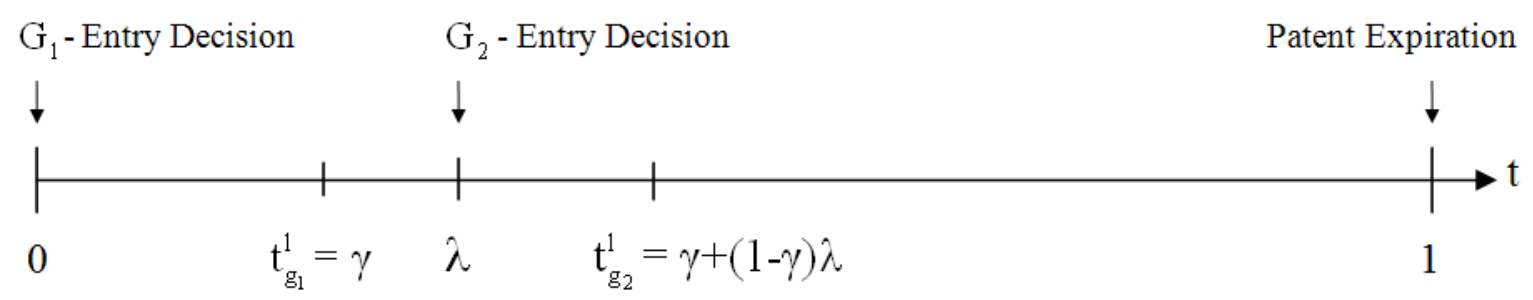

Suppose, for example, that at the point in time $G_{1}$ challenges $O$ 's patent, the remaining life of the patent is 10 years and the probability of patent validity 20 percent (i.e., $\gamma=0.2$ ). Then, $G_{1}$ 's expected entry date under litigation is equal to 2 years from the point in time $G_{1}$ challenges the patent $\left(t_{g_{1}}^{l}=\gamma \cdot 10\right.$ years $)$. If $G_{2}$ challenges $O$ 's patent three years later than $G_{1}$ (so that $\lambda=0.3$ ), the remaining life of the patent is 7 years. Thus, $G_{2}$ 's expected entry date under litigation is equal to 1.4 years from the point in time $G_{2}$ challenges the patent and 4.4 years from the point in time $G_{1}$ challenges the patent $\left(t_{g_{2}}^{l}=\gamma \cdot 10\right.$ years $+(1-\gamma) \cdot \lambda \cdot 10$ years $)$.

For simplification, we assume that no other substitutes are available to the originators' patents. Thus, in the absence of generic entry, the market exhibits a monopoly and $O$ makes profits $\pi^{m}$. If $G_{1}$ enters, the market will exhibit a duopoly and $O$ and $G_{1}$ will make profits $\pi_{o}^{d}$ and $\pi_{g}^{d}$. If $G_{2}$ additionally enters, the market will exhibit a triopoly and companies will make profits $\pi_{o}^{t}$ and $\pi_{g}^{t}$. We assume that all companies have identical production technologies. However, the profits $G_{1}$ and $G_{2}$ can make are strictly lower than that of $O$ as their products are perceived inferior by consumers. ${ }^{13}$

\footnotetext{
${ }^{11}$ In accordance with our assumption that companies view settlements as superior to litigation, $G_{1}$ expects $G_{2}$ to settle or to stay off the market when itself litigates.

${ }^{12}$ Note that settlements are not necessarily desirable from a consumer welfare perspective as they only lead to inter partes clarification (among settling parties) while litigations, if the outcome is in favor of the generic companies, have erga omnis obligation (also apply to third parties). If $O$ and $G_{1}$ settle, $G_{2}$ will only be able to enter when it has the means to litigate itself. While if $O$ and $G_{1}$ litigate and the patent gets invalidated, $G_{2}$ will be free to enter immediately. Settlements can, however, not be prohibited, they can only be regulated.

${ }^{13}$ For statistics showing that generic products are perceived as inferior by consumers see, e.g., European Commission (2008, para. 171, 189, and Table 12).
} 
Settlements are ruled by courts. The ruling affects the settlement terms, i.e., the generic entry dates that settling companies agree upon, and generic companies' incentives to enter and to challenge probabilistic patents in the first place. Specifically, the more settling companies collude under a rule, meaning the more they delay generic entry compared to litigation, the higher are their expected settlement profits and thus generic companies' incentives to enter.

Collusion increases settling companies' profits because it implies a prolongation of monopoly (or duopoly), through which a surplus $s$ is generated. We assume that settling companies divide this surplus equally among them, that is, the originator company receives the same share in surplus as any of the generic companies. The higher the share in surplus that generic companies receive, the higher are their expected settlement profits, and thus their incentives to enter when collusion is possible. ${ }^{14}$

We apply the consumer welfare standard to assess which rule is most favorable. Absent generic entry, the market exhibits a monopoly between $t=0$ and $t=1$. Whereas with generic entry, the market exhibits a monopoly between $t=0$ and $t_{g_{1}}$, a duopoly between $t_{g_{1}}$ and $t_{g_{2}}$, and a triopoly between $t_{g_{2}}$ and $t=1$. It follows that collusion affects consumer welfare negatively as it implies a delay in $t_{g_{1}}$ and $t_{g_{2}}$ under each concluded settlement. Collusion may, however, also have a positive effect as generic companies' incentives to enter increase, so that more settlements are concluded. Consumer welfare under the additional settlements is higher than under monopoly given $t_{g_{1}}<1$ and $t_{g_{2}} \leq 1$, i.e., given collusion is limited. Thus, there exists the tradeoff that the more settling companies collude under a rule, the more competition is restrained under each concluded settlement, but the higher is the number of concluded settlements.

\section{Equilibrium Analysis}

In this section, we analyze how the choice of the rule affects the degree of collusion and generic companies' incentives to enter. To assess the degree of collusion we ask by how much settling companies delay generic entry compared to litigation. And to assess generic companies' incentives to enter we ask for which values of patent strength they find it profitable to enter.

\footnotetext{
${ }^{14}$ In Appendix A3, we do not assume that settling companies share the surplus equally but compute the Nash Bargaining solution. Under the Nash Bargaining solution generic companies also receive a positive share in surplus. Note, if they received no share in surplus, collusion would not have an incentive effect and then the rule of per se illegality would always outperform the rule of reason.
} 


\subsection{Equilibria under the Rule of Per Se Illegality}

Under the rule of per se illegality (denoted $p i$ ) payments from originator to generic companies within settlement agreements are per se illegal. The companies can negotiate over generic entry but originator companies cannot compensate generic companies for a delay in entry compared to litigation. Because compensations are not possible, no party is willing to accept less favorable entry terms than the ones expected under litigation. The companies therefore agree upon $t^{p i}=t^{l}$. They do not collude. Accordingly, the companies' settlement profits are equal to their expected litigation profits: ${ }^{15}$

$$
\begin{array}{r}
\pi_{o}^{p i} \equiv \pi_{o}^{l}= \begin{cases}\gamma \pi^{m}+(1-\gamma)\left[\lambda \pi_{o}^{d}+(1-\lambda) \pi_{o}^{t}\right] & \text { if } \gamma \in\left[0, \gamma_{g_{2}}^{p i}\right] \\
\gamma \pi^{m}+(1-\gamma) \pi_{o}^{d} & \text { if } \gamma \in\left(\gamma_{g_{2}}^{p i}, \gamma_{g_{1}}^{p i}\right] \\
\pi^{m} & \text { if } \gamma \in\left(\gamma_{g_{1}}^{p i}, 1\right]\end{cases} \\
\pi_{g_{1}}^{p i} \equiv \pi_{g_{1}}^{l}= \begin{cases}(1-\gamma)\left[\lambda \pi_{g}^{d}+(1-\lambda) \pi_{g}^{t}\right] & \text { if } \gamma \in\left[0, \gamma_{g_{2}}^{p i}\right] \\
(1-\gamma) \pi_{g}^{d} & \text { if } \gamma \in\left(\gamma_{g_{2}}^{p i}, \gamma_{g_{1}}^{p i}\right] \\
0 & \text { if } \gamma \in\left(\gamma_{g_{1}}^{p i}, 1\right]\end{cases} \\
\pi_{g_{2}}^{p i} \equiv \pi_{g_{2}}^{l}= \begin{cases}(1-\gamma)(1-\lambda) \pi_{g}^{t} & \text { if } \gamma \in\left[0, \gamma_{g_{2}}^{p i}\right] \\
0 & \text { if } \gamma \in\left(\gamma_{g_{2}}^{p i}, 1\right] .\end{cases}
\end{array}
$$

Here, $\gamma_{g_{1}}^{p i}$ and $\gamma_{g_{2}}^{p i}$ describe the critical values of patent strength for which the generic companies are indifferent between entering or not. They are defined by

$$
\begin{array}{ll}
\pi_{g_{1}}^{l}(\gamma)+\frac{s^{p i}}{2}-f_{g}=0 & \Leftrightarrow \gamma_{g_{1}}^{p i}=1-\frac{f_{g}-\frac{s^{p i}}{2}}{\pi_{g}^{d}}, \\
\pi_{g_{2}}^{l}(\gamma)+\frac{s^{p i}}{3}-f_{g}=0 & \Leftrightarrow \gamma_{g_{2}}^{p i}=1-\frac{f_{g}-\frac{s^{p i}}{3}}{(1-\lambda) \pi_{g}^{t}} .
\end{array}
$$

The surplus, $s^{p i}$, generated through settlements compared to litigations, is zero under this rule. ${ }^{16} \gamma_{g_{1}}^{p i}$ and $\gamma_{g_{2}}^{p i}$ show for which values of patent strength the companies find it profitable to enter: $G_{1}$ enters for $\gamma \in\left[0, \gamma_{g_{1}}^{p i}\right]$ and $G_{2}$ enters for $\gamma \in\left[0, \gamma_{g_{2}}^{p i}\right]$. Since $G_{2}$ 's entry decision is delayed, its expected settlement profits are lower than $G_{1}$ 's, and so $\gamma_{g_{2}}^{p i}<\gamma_{g_{1}}^{p i}$. This is illustrated in Figure 1, which plots generic and originator companies' expected settlement profits $\left(\pi_{o}^{p i}, \pi_{g_{1}}^{p i}, \pi_{g_{2}}^{p i}\right)$ and their fixed entry costs $\left(f_{o}(\gamma), f_{g}\right)$ against values of patent strength $(\gamma)$. We look at a marketplace, in which originators hold patents that would be declared valid by courts with probabilities $\gamma \in[0,1]$.

The figure shows that the generic companies' expected settlement profits decrease with the probability of patent validity, i.e., with the patents' strength. This is because

\footnotetext{
${ }^{15}$ For simplification we do not consider litigation and settlement costs here but in Appendix A3.

${ }^{16}$ The surplus is divided by three if $G_{1}$ and $G_{2}$ enter and by two if only $G_{1}$ enters.
} 


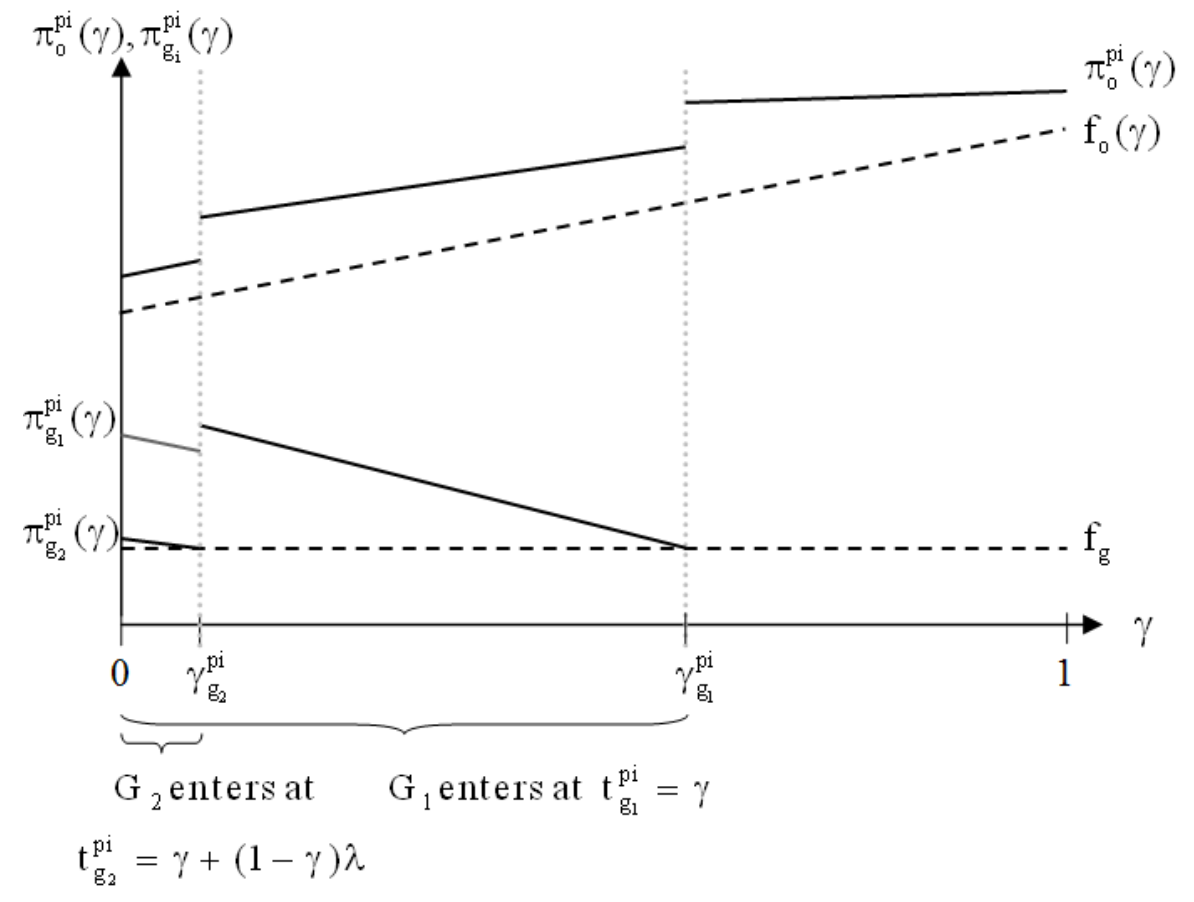

the companies will settle upon later entry dates if the probability of patent validity is higher. For each value of patent strength $G_{1}$ 's expected settlement profits are higher than that of $G_{2}$ as it enters earlier. Consequently, $G_{1}$ can cover the fixed costs $f_{g}$ for values of patent strength $\gamma \in\left[0, \gamma_{g_{1}}^{p i}\right]$, while $G_{2}$ can cover $f_{g}$ only for $\gamma \in\left[0, \gamma_{g_{2}}^{p i}\right]$, with $\gamma_{g_{2}}^{p i}<\gamma_{g_{1}}^{p i}$. It follows, when $\gamma \in\left[0, \gamma_{g_{2}}^{p i}\right]$ both generic companies enter. In that case, monopoly lasts from $t=0$ to $t_{g_{1}}^{p i}=\gamma$, duopoly from $t_{g_{1}}^{p i}=\gamma$ to $t_{g_{2}}^{p i}=\gamma+(1-\gamma) \lambda$, and triopoly from $t_{g_{2}}^{p i}=\gamma+(1-\gamma) \lambda$ to $t=1$. Instead, when $\gamma \in\left(\gamma_{g_{2}}^{p i}, \gamma_{g_{1}}^{p i}\right]$ only $G_{1}$ enters and duopoly lasts from $t_{g_{1}}^{p i}=\gamma$ to $t=1$. Further, when $\gamma \in\left(\gamma_{g_{1}}^{p i}, 1\right]$ no generic company enters and monopoly lasts from $t=0$ to $t=1$.

Result 1 Under the rule of per se illegality value transfers within settlement agreements are illegal, so that originator companies cannot compensate generic companies for a delay in entry compared to litigation. The companies settle on generic entry terms that would in expectation result under litigation. Collusion does not arise.

\subsection{Equilibria under the Rule of Per Se Legality}

Under the rule of per se legality (denoted $p l$ ) payments from originator to generic companies are per se legal. The companies can negotiate over generic entry and originator companies can compensate generic companies for any delay in entry compared to litigation. They therefore settle on entry terms that maximize their joint profits. Since 
joint profits,

$$
\Pi^{p l}=t_{g_{1}}^{p l} \pi^{m}+\left(t_{g_{2}}^{p l}-t_{g_{1}}^{p l}\right)\left(\pi_{o}^{d}+\pi_{g}^{d}\right)+\left(1-t_{g_{2}}^{p l}\right)\left(\pi_{o}^{t}+2 \pi_{g}^{t}\right),
$$

are an increasing function of $t_{g_{1}}^{p l}$ and $t_{g_{2}}^{p l}$, they choose the latest possible entry dates, i.e., $t_{g_{1}}^{p l}=t_{g_{2}}^{p l}=1 .{ }^{17}$ Monopoly is sustained for the whole patent duration. That is, collusion is maximal.

Settling companies create a surplus compared to litigation equal to

$$
\begin{aligned}
& s_{1}^{p l}=(1-\gamma)\left[\pi^{m}-\lambda\left(\pi_{o}^{d}+\pi_{g}^{d}\right)-(1-\lambda)\left(\pi_{o}^{t}+2 \pi_{g}^{t}\right)\right] \quad \text { if } \gamma \in\left[0, \gamma_{g_{2}}^{p l}\right] \text {, } \\
& s_{2}^{p l}=(1-\gamma)\left[\pi^{m}-\pi_{o}^{d}-\pi_{g}^{d}\right] \quad \text { if } \gamma \in\left(\gamma_{g_{2}}^{p l}, \gamma_{g_{1}}^{p l}\right] .
\end{aligned}
$$

Because the generated surplus is higher than under the rule of per se illegality, the companies' expected settlement profits increase. As a result the critical levels of patent strength, for which the generic companies are indifferent between entering or not, are higher:

$$
\gamma_{g_{1}}^{p l}=1-\frac{f_{g}-\frac{s_{2}^{p l}}{2}}{\pi_{g}^{d}} \quad \text { and } \quad \gamma_{g_{2}}^{p l}=1-\frac{f_{g}-\frac{s_{1}^{p l}}{3}}{(1-\lambda) \pi_{g}^{t}} .
$$

This means, generic entry takes place more often than under the rule of per se illegality. However, competition does not enhance due to the additional patent challenges. Under all concluded settlements monopoly lasts from $t=0$ until $t=1$.

Result 2 Under the rule of per se legality value transfers within settlement agreements are legal, so that originator companies can compensate generic companies for a delay in entry compared to litigation. The companies maximize their joint profits by delaying generic entry until the end of patent duration. Collusion is maximal.

\subsection{Equilibria under the Rule of Reason}

The rule of reason (denoted $r r$ ) is usually implemented as a three-step process. Initially, the plaintiffs may show whether there are adverse effects on competition. Subsequently, the defendants may "establish procompetitive redeeming virtues of the action." And finally, the plaintiffs may "show that the same procompetitive effects could not be achieved through an alternative means that is less restrictive of competition." ${ }^{18}$ In case of patent settlements, plaintiffs can only make use of indicators for adverse ef-

\footnotetext{
${ }^{17}$ Agreements determining generic entry dates later than $t^{p l}=1$ would be illegal by competition law as at stage $t=1$ the status of the patent terminates. Accordingly, an agreement that guaranteed to Hoechst Marion Rousselt that its generic competitor, Andrx, would, for the price of $\$ 10$ million per quarter, refrain from marketing its generic version of Cardizem CD even after it had obtained FDA approval, has been judged anticompetitive.

${ }^{18}$ Citing Clorox Co. vs. Sterling Winthrop, 117 F.3d 50 (2d Cir. 1997).
} 
fects on competition in the first step. ${ }^{19}$ Consequently, the insights that courts obtain will presumably be incomplete. This means, courts will presumably only have vague ideas of whether particular settlement agreements are pro- or anticompetitive, making consumers better or worse off compared to litigation. Therefore, we assume that courts predict the expected generic entry dates under litigation with errors $\epsilon$, such that $\hat{t}^{l}=t^{l}+\epsilon{ }^{20}$ These errors, $\epsilon$, are uniformly distributed between $e$ and $-e$, that is, $\epsilon \sim U[-e, e]$. An increase in $e$ means courts' predictions of $t^{l}$ become less precise, or put differently, the chance that courts approve anticompetitive settlements increases.

Accordingly, courts prohibit settlements if the generic entry date that the companies agreed upon lies post to the predicted entry date under litigation $\left(t^{r r}>\hat{t}^{l}\right)$. In case of prohibition, the companies have to execute less restrictive agreements where such agreements are available. We assume that the resulting entry terms are neutral in case of prohibition $\left(t^{r r}=t^{l}\right)$. We further assume, if courts prohibit a first settlement between $O$ and $G_{1}$, they will also prohibit a second settlement between $O$ and $G_{2}$ that assigns a corresponding entry date. ${ }^{21}$ The probability with which courts prohibit first settlements is

$$
\operatorname{Prob}\left(t_{g_{1}}^{r r}>\hat{t}_{g_{1}}^{l}\right)=\operatorname{Prob}\left(\epsilon<t_{g_{1}}^{r r}-\gamma\right)=\frac{t_{g_{1}}^{r r}-\gamma+e}{2 e} .
$$

Given this probability, companies' expected joint settlement profits are

$$
\Pi^{r r}=\left\{\begin{array}{l}
\frac{t_{g_{1}}^{r r}-\gamma+e}{2 e}\left[\gamma \pi^{m}+(1-\gamma)\left[\lambda\left(\pi_{o}^{d}+\pi_{g}^{d}\right)+(1-\lambda)\left(\pi_{o}^{t}+2 \pi_{g}^{t}\right)\right]\right] \\
+\frac{e-t_{g_{1}}^{r r}+\gamma}{2 e}\left[t_{g_{1}}^{r r} \pi^{m}+\left(1-t_{g_{1}}^{r r}\right)\left[\lambda\left(\pi_{o}^{d}+\pi_{g}^{d}\right)+(1-\lambda)\left(\pi_{o}^{t}+2 \pi_{g}^{t}\right)\right]\right], \quad \text { if } \gamma \in\left[0, \gamma_{g_{2}}^{r r}\right], \\
\frac{t_{g_{1}}^{r r}-\gamma+e}{2 e}\left[\gamma \pi^{m}+(1-\gamma)\left(\pi_{o}^{d}+\pi_{g}^{d}\right)\right] \\
+\frac{e-t_{g_{1}}^{r r}+\gamma}{2 e}\left[t_{g_{1}}^{r r} \pi^{m}+\left(1-t_{g_{1}}^{r r}\right)\left(\pi_{o}^{d}+\pi_{g}^{d}\right)\right], \quad \text { if } \gamma \in\left(\gamma_{g_{2}}^{r r}, \gamma_{g_{1}}^{r r}\right] .
\end{array}\right.
$$

The companies maximize these expected joint settlement profits by agreeing upon entry dates $t_{g_{1}}^{r r}=\min [\gamma+e / 2,1]$ and $t_{g_{2}}^{r r}=\min \left[t_{g_{1}}^{r r}+\left(1-t_{g_{1}}^{r r}\right) \lambda, 1\right]$. This gives us the following result.

Result 3 Under the rule of reason companies are allowed to transfer values within

\footnotetext{
${ }^{19}$ Indicators for adverse effects include the amounts of value transfers relative to the patents' market value or the agreed upon generic entry dates. Further, plaintiffs can gather evidence through search for prior art, and through examinations of backward citations and patent claims in the patent applications.

${ }^{20}$ It is natural to assume that predictions of $\hat{t}^{l}>1$ or $\hat{t}^{l}<0$ do not occur as these would be predictions that a patent is valid with more than $100 \%$ or less than $0 \%$, respectively.

${ }^{21}$ If the first settlement assigns $t_{g_{1}}^{r r}$, the corresponding entry date of a second settlement would be $t_{g_{2}}^{r r}=t_{g_{1}}^{r r}+\left(1-t_{g_{1}}^{r r}\right) \lambda$ because $t_{g_{1}}^{l}=\gamma$ and $t_{g_{2}}^{l}=\gamma+(1-\gamma) \lambda$.
} 
settlements but courts prohibit settlements which they regard anticompetitive. The less precisely courts evaluate settlements, the more companies collude because the higher is the chance that their anticompetitive settlements get approved.

When deciding on generic entry dates settling companies face the following tradeoff. The more they collude, the higher profits they obtain in case of settlement approval but the higher is also the probability that their settlement gets prohibited. If courts evaluate settlement agreements more precisely, so that anticompetitive settlements get more likely prohibited, it will pay less for the companies to choose particularly late generic entry dates.

In this section, we restrict our attention to the case when companies optimally choose $t_{g_{1}}^{r r}=\gamma+e / 2<1 .{ }^{22}$ Inserting $t_{g_{1}}^{r r}=\gamma+e / 2$ into equation (1) shows that courts approve settlements with probability $\operatorname{Prob}\left(t_{g_{1}}^{r r}<\hat{t}_{g_{1}}^{l}\right)=1 / 4$. In that case, the companies generate a surplus compared to litigation equal to

$$
\begin{array}{ll}
s_{1}^{r r}=\frac{e}{2}\left[\pi^{m}-\lambda\left(\pi_{o}^{d}+\pi_{g}^{d}\right)-(1-\lambda)\left(\pi_{o}^{t}+2 \pi_{g}^{t}\right)\right] & \text { if } \gamma \in\left[0, \gamma_{g_{2}}^{r r}\right], \\
s_{2}^{r r}=\frac{e}{2}\left[\pi^{m}-\pi_{o}^{d}-\pi_{g}^{d}\right] & \text { if } \gamma \in\left(\gamma_{g_{2}}^{r r}, \gamma_{g_{1}}^{r r}\right] .
\end{array}
$$

The critical levels of patent strength, for which the generic companies are indifferent between entering or not, are given by

$$
\gamma_{g_{1}}^{r r}=1-\frac{f_{g}-\frac{s_{2}^{r r}}{8}}{\pi_{g}^{d}}, \quad \text { and } \quad \gamma_{g_{2}}^{r r}=1-\frac{f_{g}-\frac{s_{1}^{r r}}{12}}{(1-\lambda) \pi_{g}^{t}} .
$$

It is easy to see that the generated surplus and thus the critical levels of patent strength increase with $e$, i.e., with the imprecision of antitrust evaluations. The larger $e$, the more the companies collude and the higher are generic companies' incentives to enter.

Result 4 By colluding, settling companies generate a surplus which they can divide among each other. That way, expected settlement profits increase, and generic companies obtain additional incentives to enter.

\section{Welfare Analysis}

A central question of this paper is under which conditions which rule toward payfor-delay settlements is preferable from a consumer welfare perspective. The previous analysis has shown that under the rule of per se legality settling companies sustain monopoly for the whole patent duration. Thus, initiated challenges do not lead to

\footnotetext{
${ }^{22}$ We analyze the case when companies optimally choose $t_{g_{1}}^{r r}=1$ in Appendix A1.
} 
increased competition. For all values of patent strength, monopoly lasts from $t=0$ to $t=1$. This is different under the rule of per se illegality and under the rule of reason. Under these alternative rules initiated challenges of weaker patents lead to increased competition. Therefore, we obtain the following result.

Result 5 Only under the rule of per se legality patent challenges do not lead to increased competition. Thus, the rule of per se legality yields the lowest consumer welfare.

What remains unanswered is under which conditions the rule of reason or the rule of per se illegality yields the higher consumer welfare. We know that under these two rules the companies settle upon:

$$
\begin{array}{lll}
t_{g_{1}}^{p i}=\gamma & \text { and } \quad t_{g_{2}}^{p i}=\gamma+(1-\gamma) \lambda \\
t_{g_{1}}^{r r}=\gamma+\frac{e}{2} & \text { and } \quad t_{g_{2}}^{r r}=\gamma+\frac{e}{2}+\left(1-\gamma-\frac{e}{2}\right) \lambda
\end{array}
$$

Here, $e$ shows how precisely courts evaluate patent settlements under the rule of reason. If courts are able to evaluate patent settlements without error, $e$ equals zero. In that case, generic entry and consumer welfare is the same under both rules. Thus, when a marginal increase in $e$, at the point where $e=0$, improves consumers welfare under the rule of reason, patent settlements should be treated under this standard. We obtain the following the result.

The rule of reason yields higher consumer welfare than the rule of per se illegality if generic companies' incentives to challenge probabilistic patents are sufficiently weak, i.e., if $\gamma_{g_{1}}^{r r}<\gamma_{g_{1}}^{r r^{\prime}} \equiv \frac{\Delta_{1}}{\Delta_{1}+2 \pi_{g}^{d}}$ and $\gamma_{g_{2}}^{r r}<\gamma_{g_{2}}^{r r^{\prime}} \equiv \frac{\Delta_{2}}{\Delta_{2}+3(1-\lambda) \pi_{g}^{t}}$ with $\Delta_{1}=\pi^{m}-\pi_{o}^{d}-\pi_{g}^{d}$ and $\Delta_{2}=\pi^{m}-\lambda\left(\pi_{o}^{d}+\pi_{g}^{d}\right)-(1-\lambda)\left(\pi_{o}^{t}+2 \pi_{g}^{t}\right)$. The proof is relegated to Appendix B. Proposition 4 shows that central to the condition ensuring that the rule of reason outperforms the rule of per se illegality is, how strong generic companies' incentives to challenge probabilistic patents are. If generic companies' incentives to enter are low, the rule of reason likely outperforms the rule of per se illegality. Generic companies' incentives to enter depend negatively on their fixed entry costs $f_{g}$ and positively on their expected settlement profits $\pi_{g}$ (see also Figure 1). As shown in Appendix B, the condition in Proposition 4 can be rewritten as

$$
f_{g_{1}}>\frac{2 \pi_{g}^{d^{2}}}{2 \pi_{g}^{d}+\Delta_{1}} \quad \text { and } f_{g_{2}}>\frac{3\left((1-\lambda) \pi_{g}^{t}\right)^{2}}{(1-\lambda) \pi_{g}^{t}+\Delta_{2}} .
$$

The fixed costs consist of proving bioequivalence and of bringing forward arguments why the originator's patent could potentially be invalid or non-infringed. They vary with the type of challenge. A non-infringement claim, if readily available, is generally 
easier to conduct than an invalidity claim. ${ }^{23}$ Generic companies' expected settlement profits depend on numerous factors, inter alia on the extent to which consumers perceive generic products as inferior to original products.

The explanation for why the rule of reason outperforms the rule of per se legality when generic companies' incentives to enter are low is the following. The rule of reason outperforms the rule of per se illegality when a marginal increase in $e$, at the point where $e=0$, has positive welfare implications. A marginal increase of $e$ induces settling companies to collude. This affects consumer welfare positively when the negative effect adhered to collusion that under each concluded settlement generic entry is delayed, is outweighed by the positive effect adhered to collusion that additional settlements result as generic companies obtain higher incentives to enter. The negative "entry delay" effect is small when generic companies' incentives to enter are low because in that case, overall, few settlements are concluded. Since under each settlement entry is equally delayed, the total negative effect remains small. At the same time, the positive "incentive effect" is big when generic companies' incentives to enter are low because the additional patents that get challenged are of relatively weak strength, which implies that under the additional settlements the companies choose relatively early entry dates and so, competition increases strongly. If, on the other hand, generic companies' incentives to enter were high and the additional patents that get challenged strong, companies would choose late generic entry dates under the additional settlements and so, the degree of competition would only weakly improve.

This can be inferred from Figure 2. Here, consumer welfare $(C W)$ is plotted against patent strength $(\gamma) . C W^{c}$ denotes consumer welfare under competition when generic entry occurs immediately and $C W^{m}$ denotes consumer welfare under monopoly when generic entry occurs at the end of patent duration. Generic companies enter for values of patent strength between 0 and $\gamma^{r r}$. So, a low $\gamma^{r r}$ indicates that generic companies' incentives to enter are low. The figure shows the effects of successive marginal increases in $e$. An increase in $e$ has the negative effect that under each concluded settlement consumer welfare decreases as the companies delay entry. It can be seen, when $\gamma^{r r}$ is low, the number of concluded settlements is low, so that the aggregate entry delay effect remains low. Further, an increase in $e$ has the positive effect that $\gamma^{r r}$ increases, meaning generic companies obtain higher incentives to enter and additional settlements

\footnotetext{
${ }^{23}$ In Schering-Plough vs. FTC, for instance, the active ingredient of Schering-Plough's pharmaceutical was an unpatented potassium salt, so that two generic companies could relatively easily come up with alternative, non-infringing means of achieving bioequivalence.
} 
are concluded. When $\gamma^{r r}$ is low, consumer welfare increases strongly because the additional patents that get challenged are of relatively low strength, implying that the companies settle upon early generic entry dates. When entry occurs earlier, consumer welfare increases by more.

Figure 2: EFFECTS OF A MARGINAL INCREASE OF $e$ ON CONSUMER WELFARE
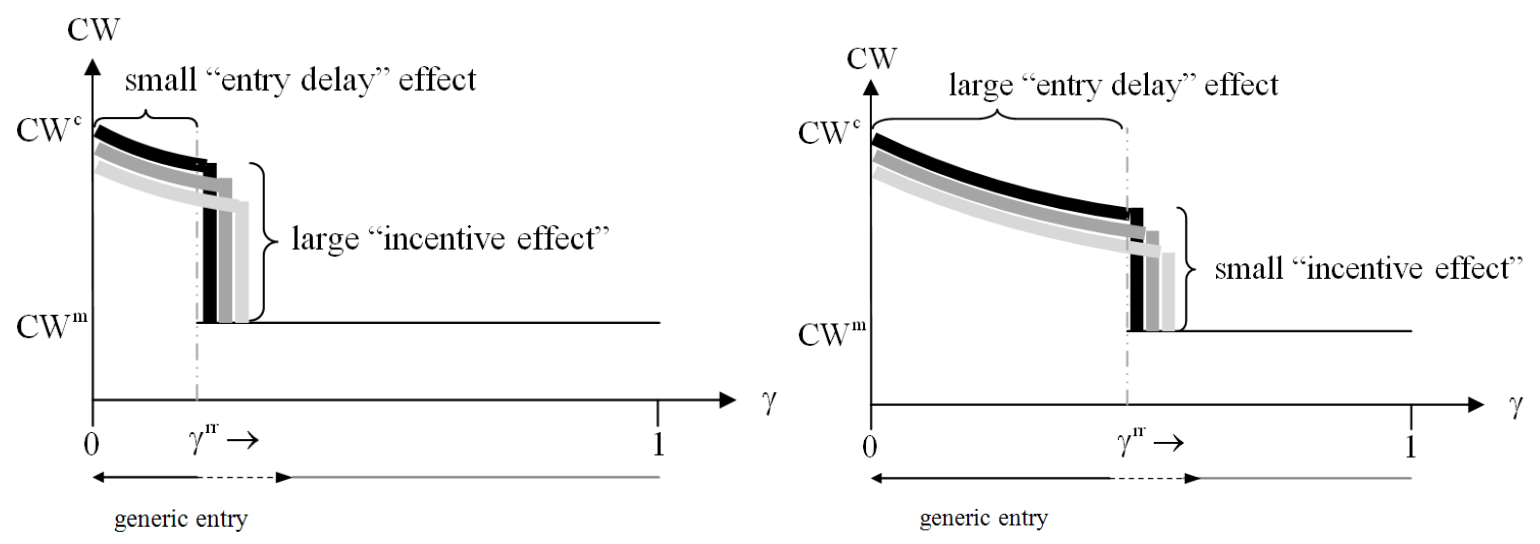

\section{Welfare Implications of the Hatch-Waxman Act}

The welfare analysis showed that the application of the rule of reason toward pay-fordelay settlements can yield higher consumer welfare than the application of the rule of per se illegality because settling companies are induced to collude, which increases generic companies' expected settlement profits and with it their incentives to challenge probabilistic patents. Incentivization is achieved through restraints of competition between originator and generic companies. If there was no lack of incentives, the rule of reason would clearly yield lower consumer welfare than the rule of per se illegality. The question arises how strong generic companies' incentives to challenge contestable patents are in practice. And moreover, we may bring into question whether it is effective to let settling parties collude in order to achieve incentivization.

Due to lack of data, researchers have not empirically tested how strong generic companies' incentives to challenge probabilistic patents are in practice. We know, however, if it comes to patent litigation, the risk that the patents will be declared invalid or non-infringed by courts is substantial. The FTC (2002) calculated that in $73 \%$ of Hatch-Waxman cases (see below), the generic company was found not to have infringed a valid patent. ${ }^{24}$ This indicates that generic companies are only willing to

\footnotetext{
${ }^{24}$ Further information about generic companies' incentives to challenge probabilistic patents across countries can be inferred from factors like number of settlements in relation to product market values
} 
involve originator companies in patent disputes when their chances of winning are relatively high. Presumably, generic companies only challenge probabilistic patents of relatively low strength or high commercial value. ${ }^{25}$

To foster generic entry, competition authorities could alternatively strengthen generic companies' market power. For instance, they could encourage the prescription of generic products. However, in the first instance this would presumably lead to an increase in the number of generic companies in the market, and thus not necessarily provide each individual generic company stronger incentives to enter.

A prominent alternative incentive device is the provision of an exclusivity right to first generic entrants as implemented within the Hatch-Waxman Act (HWA) of 1984 in the US. ${ }^{26}$ The HWA awards first generic applicants to file an Abbreviated New Drug Application (ANDA) containing a paragraph IV certification with 180 days of marketing exclusivity, during which the Food and Drug Administration (FDA) may not approve a subsequent generic applicant's ANDA for the same pharmaceutical product (21 U.S.C. $\S 355(\mathrm{j})(5)(\mathrm{B})(\mathrm{iv})){ }^{27}$

The 180 days of marketing exclusivity implies a restraint of competition between generic companies. It increases first generic companies' expected profits and thus provides them higher incentives to enter and to challenge probabilistic patents, given subsequent generic companies would have entered. ${ }^{28}$ The question is, whether it also provides them higher incentives to challenge additional probabilistic patents. In what follows, we will show that this is not the case. Since subsequent generic companies' incentives to enter decline, the effect of the HWA provisions is anticompetitive.

The effect of the HWA provisions is anticompetitive because first generic companies' incentives to challenge additional probabilistic patents do not improve $\left(\gamma_{g_{1}}^{\text {hwa }} \equiv \gamma_{g_{1}}\right)$ but subsequent generic companies' incentives to challenge probabilistic patents decline

(see, e.g., EC 2008, Figure 97).

${ }^{25}$ Judge Posner stressed the importance of generic companies' incentives to challenge patents in Asahi Glass Co. v. Pentech Pharmaceuticals. The Asahi approach has been repeated and approved in cases Tamoxifen, Schering-Plough vs. FTC, In re Cipro, and further in papers by Balto (2004), and Schildkraut (2004).

${ }^{26}$ The Hatch-Waxman Act is formally known as Drug Price Competition and Patent Restauration Act of 1984, Pub.L.No 98-417, 98 Stat. 1585 (1984).

${ }^{27}$ The 180-day exclusivity period is calculated from either (i) first commercial marketing by the first generic applicant, or (ii) a decision of a court holding the relevant patents to be invalid or not infringed. The marketing exclusivity forfeits and subsequent applicants can enter at the same time as the first applicant when (i) an appeals court has ruled the relevant patents invalid or not infringed and (ii) 75 days after the effective date or 30 month after application filing elapsed. When the originator files within 45 days a patent infringement suit against any generic company that submits an ANDA, FDA's approval of the ANDA stays for at least 30 month during which time no generic can be launched.

${ }^{28}$ Apotex, for instance, reported it earned between $\$ 150$ million and $\$ 200$ million from its marketing exclusivity on the antidepressant Paxil. 
$\left(\gamma_{g_{2}}^{h w a}<\gamma_{g_{2}}\right)$

The proof is relegated to Appendix B. It has been presumed that the provision of exclusivity rights to first generic companies improves their incentives to enter, so that additional challenges result. However, the HWA provisions only lead to an increase in first generic companies' profits, improving their incentives to enter, when they find it profitable to enter anyway. This is because first generic companies have higher incentives to enter than subsequent generic companies, and the HWA provisions only lead to restraints of competition when subsequent entry would have occurred. ${ }^{29}$ Thus, only when first generic companies find it profitable to enter anyway they obtain additional profits due to the HWA provisions. Put another way, when first generic companies do not find it profitable to enter and an increase in their profits would be desirable, leading to additional patent challenges, subsequent generic companies do not find it profitable to enter either, and therefore, an exclusivity right that restricts generic competition does not improve first generic companies' incentives to enter.

Figure 3: The EFFECT OF THE HWA PROVISIONS ON GENERIC COMPANIES' INCENTIVES TO ENTER

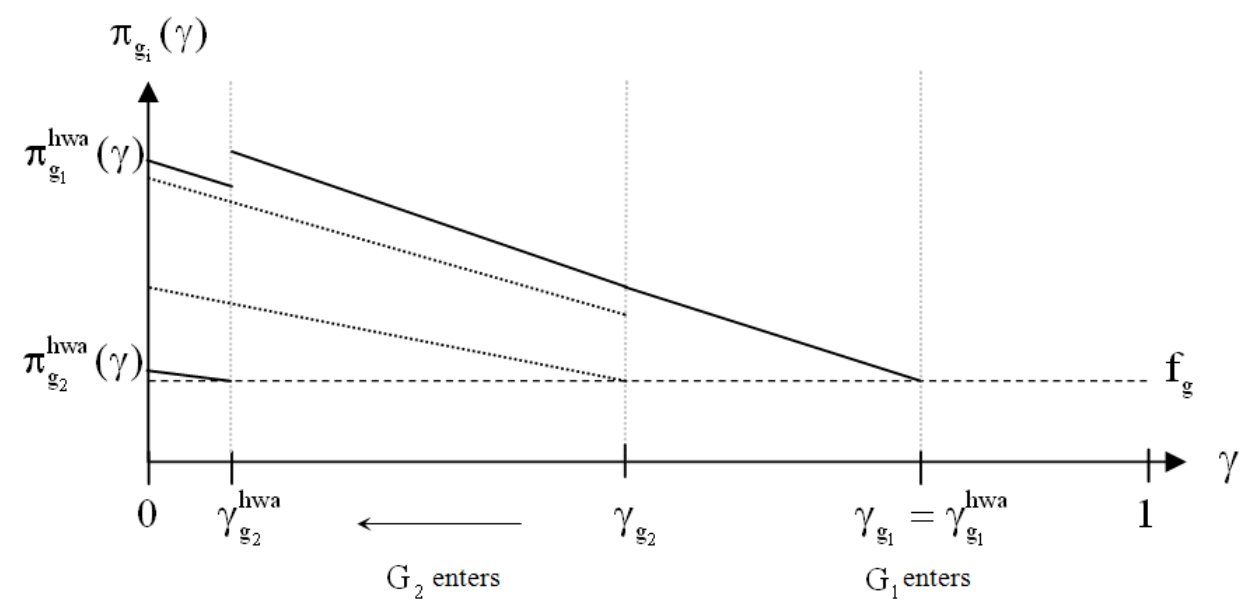

Note: The drawn through lines show generic companies' expected settlement profits under the HWA, while the dotted lines show their expected settlement profits absent the HWA.

The argument is illustrated in Figure 3. It shows that second generic companies' expected settlement profits and thus their incentives to enter decrease under the HWA provisions $\left(\gamma_{g_{2}}^{h w a}<\gamma_{g_{2}}\right)$. First generic companies' expected settlement profits, on the other hand, increase, but only for values of $\gamma \in\left[0, \gamma_{g_{2}}\right)$. Since first generic companies' expected settlement profits do not increase for values of $\gamma \in\left(\gamma_{g_{2}}, 1\right]$ their incentives to

\footnotetext{
${ }^{29}$ Subsequent generic companies have lower incentives to enter than first generic companies as their entry is delayed $(\lambda>0)$.
} 
enter remain unchanged $\left(\gamma_{g_{1}}^{h w a} \equiv \gamma_{g_{1}}\right)$.

Arguably, if second generic companies obtained, despite their entry delay, higher settlement profits than first generic companies (e.g., due to lower fixed entry costs or higher productive efficiency), the HWA would be effective in providing first generic companies incentives to enter for additional probabilistic patents. In that case, such incentivization would, however, not improve consumer welfare either as first generic companies would challenge additional probabilistic patents that second generic companies would challenge absent the HWA provisions anyway, since in that case second generic companies have higher incentives to enter than first generic companies (i.e., $\left.\gamma_{g_{2}}>\gamma_{g_{1}}\right)$.

Further, one could argue that the HWA provisions lead to earlier entry by first generic companies as they provide generic companies additional incentives to be the first in the market. Similar to the effect that patent races have on entry dates of originator companies, the award of an exclusivity right to first generic companies might have an effect on entry dates of first generic companies. But even if this was the case, earlier entry of first generic companies would be accompanied by later entry of subsequent generic companies.

It follows that due to the HWA provisions no additional patents get challenged, fewer patents get challenged by both generic companies and, further, if patents get challenged by both generic companies, entry by second generic companies is delayed. We can therefore conclude that the HWA provisions do not establish the desired incentive effect, they only restrict competition when this is undesirable. Therefore, we recommend to abolish the provision of exclusivity rights to first generic entrants. ${ }^{30}$

\section{Discussion}

In this section, we discuss our results. We ask whether the problem of anticompetitive pay-for-delay settlements could be alleviated by raising patent quality across-the-board. We explain problems adhered to the rule of reason approach. And further, we ask

\footnotetext{
${ }^{30}$ Because the HWA provisions have the additional detrimental effect that originator companies basically only need to pay to delay entry by first generic companies in order to also delay entry by subsequent generic companies, Lemley and Hemphill (2011) suggest that first generic companies should only be awarded with an exclusivity right if they successfully defeat the originator companies (e.g., by invalidating their patents). We would like to point out that this kind of regulation would have the additional beneficial effect that generic companies' incentives to litigate would increase. When first generic companies are successful in litigations, this benefits subsequent generic companies and leads to increased competition overall (see supra note 12).
} 
whether in case of pay-for-delay settlements static efficiency is an acceptable criterion for long-run consumer welfare.

\subsection{Patent Quality and Effective Opposition}

We showed that patent settlements are a means to restrict competition. Arguably, policymakers could get to the root of the problem by strengthening the examination process, thereby raising patent quality across-the-board. Better funding of patent examinations, higher standards for initial review, better incentives that make it easier and more desirable for examiners to reject rather than grant patents and better incentives for applicants to disclose prior art could weed out weak patents in the first place. As several authors have stated, though, the optimal error rate at a patent office is in fact not zero. Because only very few patents have commercial significance perfect examination would not be cost effective. ${ }^{31}$ Since patent offices lack information about which patents matter ahead of time they also cannot focus their examinations on the few important patents. Thus, government relies on litigation and on an effective opposition system to fix all errors. ${ }^{32}$ However, as we pointed out in this paper, once an error has been made in the examination process and a patent dispute arises, the problem emerges that generic companies actually do not have incentives to litigate or make use of an opposition system, inducing a second review process, but to settle their disputes out of court. As long as courts apply the rule of per se legality toward payfor-delay settlements, errors made in the examination process are not corrected for to the detriment of consumers. Thus, there is an urgent need to reconsider patent law's presumption of validity and to control patent settlements by competition authorities. Only the rule of reason and the rule of per se illegality provide an effective mechanism to correct for errors made in the examination process.

\subsection{Problems Adhered to the Rule of Reason Approach}

A drawback of the rule of reason approach is that ex post competition authorities have an incentive to prohibit every pay-for-delay settlement, knowing that it is optimal for companies to settle on anticompetitive terms. As a consequence, $e$, which shows to which degree antitrust evaluations of pay-for-delay settlements are subject to error,

\footnotetext{
${ }^{31}$ Lemley (2001) points out that ninety-five percent of patents will either never be used, or will be used in circumstances that do not crucially rely on the determination of validity.

${ }^{32}$ For information on the opposition systems in the US and in the EU see, e.g., Harhoff, Scherer and Vopel (2003), Farrell and Merges (2004) and USPTO (2009).
} 
might become very small, even smaller than the theoretically optimal $e .{ }^{33}$ However, low levels of $e$ are desirable because they are likely to cause high positive incentive and low negative entry delay effects. In contrast, high levels of $e$ evidently lead to welfare losses as the negative entry delay effects grow so large that they cannot be outweighed by the positive incentive effects. So the commitment problem faced by antitrust enforcers when evaluating pay-for-delay settlements could in fact help to implement desirable levels of $e$.

It should be further noted that antitrust enforcers are likely to face practical difficulties implementing the optimal level of $e$ anyway. The optimal level of $e$ depends on many different factors and fine-tuning on $e$ is only possible through gathering more information on the merits of each case. ${ }^{34}$ Therefore, it could make sense to implement alternatively to the rule of reason, a per se rule, under which value transfers from originator to generic companies within settlement agreements are permitted up to a specific amount. Such an approach would have similar beneficial effects as the rule of reason approach but would simplify matters. By linking the permitted value transfers to originator companies' returns and keeping the permitted amounts generally low, competition authorities could appropriately balance entry delay against generic companies' incentives to challenge probabilistic patents, and at the same time assure legal certainty. Also, the administration costs would be lower than under a full-fledged rule of reason analysis.

\subsection{Static vs. Dynamic Efficiency}

In the welfare analysis we focused on static efficiency, neglecting effects that the choice of rule might have on dynamic efficiency. Static efficiency means economic efficiency at a static level, resulting from competition among existing products, whereas dynamic efficiency means economic efficiency at a dynamic level, resulting from the creation of new products. Antitrust law is mainly concerned with static efficiency, defending market competition, whereas patent law is mainly concerned with dynamic efficiency, conferring market power to innovating companies. The basis for patent law is the Schumpeterian argument, which contends that the prospect of market power

\footnotetext{
${ }^{33}$ The optimal "evaluation error" $e$ is derived in Appendix A2.

${ }^{34}$ Alternatively, competition authorities could prevent companies from choosing highly anticompetitive settlement terms by imposing a fine which the companies have to pay in case of settlement prohibition or by imposing an ad valorem tax on payments made by originator companies. These measures would make collusion more costly for the companies, so that in effect the companies would collude less.
} 
incentivizes companies to innovate. Accordingly, while competition promotes static efficiency, it might infer with dynamic efficiency. Different long-run consumer welfare implications might arise when considering dynamic efficiency. There are, however, a number of reasons one should not rely exclusively on the Schumpetarian argument. In some situations competition rather than the promise of market power promotes dynamic efficiency as it pushes companies to adopt the most efficient technologies and to invest in R\&D. ${ }^{35}$ Competition often spurs faster innovation and induces companies to innovate in different ways, resulting in a variety of different technologies. Thus, static and dynamic efficiency may go hand in hand.

When conducting a welfare analysis, we should nevertheless assess in case of restraints of competition how these restraints affect dynamic efficiency. Under the rule of per se legality and under the rule of reason competition is restrained due to collusion. So, the question arises whether collusion under these rules promotes or impairs dynamic efficiency. According to the Schumpeterian argument, originator companies might be incentivized to innovate due to the additional profits they can obtain by colluding. However, there is also an argument to the contrary. Dynamic efficiency might impair as the possibility of collusion effects that originator companies obtain relatively high profits when holding weak patents. Under the rule of per se legality, originator companies profit from collusion more if their patents are weaker. And also under the rule of reason, originator companies only profit from collusion when holding weak and not ironclad patents. This might cause originator companies to invest more in weak instead of ironclad patents. Since the effect of collusion on dynamic efficiency is not clear from the outset, this is a topic for further research.

\section{Concluding Remarks}

In the EU, regulation of pay-for-delay settlements is still in its infancy. US courts apply the rule of per se legality toward pay-for-delay settlements. This leads to tremendous welfare losses as settling companies are able to use probabilistic patent terms to legitimate restraints of competition. ${ }^{36}$ As an alternative to the rule of per se legality, courts could apply the rule of per se illegality, prohibiting settlement agreements that involve value transfers from originator to generic companies, or the rule of reason, evaluating

\footnotetext{
${ }^{35}$ This argument has long been associated with Arrow (1962).

${ }^{36}$ According to the FTC's estimations the costs to consumers in the US increase through pay-fordelay settlements by approximately $\$ 3.5$ billion each year (see Brief of the United States, available at http://www.justice.gov/atr/cases/f259300/259325.htm).
} 
pro- against anticompetitive settlement effects. We showed that in contrast to the rule of per se illegality, the rule of reason induces limited collusion between settling companies when antitrust enforcement under this rule is imperfect. On the one hand, this affects consumer welfare negatively as generic entry under each settlement is delayed. On the other hand, it affects consumer welfare positively as companies' expected settlement profits increase, which provides generic companies additional incentives to challenge probabilistic patents. Additional settlement agreements are concluded where otherwise the holders of probabilistic patents would remain monopolists. We showed that if generic companies' incentives to challenge probabilistic patents are low, the negative entry delay effect is outweighed by the positive incentive effect, so that the rule of reason yields higher consumer welfare than the rule of per se illegality.

Under the rule of reason generic entry is promoted through restraints of competition between originator and generic companies. Instead, the Hatch-Waxman Act of 1984 aims to promote generic entry through restraints of competition between generic companies. More specifically, first generic companies are awarded with an exclusivity right, which restricts entry by subsequent generic companies. The analysis revealed that this very prominent incentive device fails to have the desired effect. An increase in first generic companies' profits through restraints of competition would be desirable and would indeed lead to additional patent challenges when first generic companies do not find it profitable to enter otherwise. In these cases, however, subsequent generic companies also do not find it profitable to enter as they usually have lower incentives to enter than first generic companies as their entry is delayed. Thus, the provision of an exclusivity right to first generic companies is effectless in these cases. It still has the effect that competition is restrained when subsequent generic companies find it profitable to enter. Therefore, we recommend to abolish this regulation.

Although our analysis has shown that the application of antitrust rules toward payfor-delay settlements would be beneficial from a consumer welfare perspective, it is very difficult to justify the application of antitrust rules toward pay-for-delay settlements in front of courts. This is because pay-for-delay settlements involve (probabilistic but) valid patents. Thus, further legal research needs to be done in this direction. 


\section{Appendix A: Extensions}

\section{A1: Settlements under the Rule of Reason when $\gamma>1-\frac{e}{2}$}

In this appendix, we show that the results computed in Sections 3.3 and 4 for the rule of reason only hold for the case $\gamma>1-e / 2$ when the critical level of patent strength, for which $G_{1}$ is indifferent between entering or not, does not exceed $\gamma+e / 2$.

When $\gamma>1-e / 2$ settling companies optimally choose $t_{g_{1}}^{r r^{\prime}}=t_{g_{2}}^{r r^{\prime}}=1$ under the rule of reason. Inserting $t_{g_{1}}^{r r^{\prime}}=1$ into equation (1) shows that courts then prohibit first settlements with probability $\operatorname{Prob}\left(t^{r r^{\prime}}>\hat{t}^{l}\right)=(1-\gamma+e) / 2 e$. The critical levels of patent strength, for which the generic companies are indifferent between entering or not, change to

$$
\begin{aligned}
& \gamma_{g_{1}}^{r r^{\prime}}=\frac{f_{g}-\frac{s_{2}^{r r^{\prime}}+24}{2} e-\pi_{g}^{d}}{1-\pi_{g}^{d}}, \text { and } \\
& \gamma_{g_{2}}^{r r^{\prime}}=\frac{f_{g}-\frac{s_{1}^{r r^{\prime}}+24}{3} e-(1-\lambda) \pi_{g}^{t}}{1-(1-\lambda) \pi_{g}^{t}}
\end{aligned}
$$

when they exceed $1-e / 2$. Then, the rule of per se illegality always yields higher consumer welfare than the rule of reason because an increase in $e$ only has a negative entry delay but no positive incentive effect. A negative entry delay effect arises because settling parties are induced to collude more for values of patent strength below $1-\frac{e}{2}$. A positive incentive effect, however, does not arise because settling parties are not induced to collude more for values of patent strength above $1-\frac{e}{2}$. For these values settling companies constantly choose $t^{r r^{\prime}}=1$, regardless of whether $e$ increases or not. Thus, generic companies' expected settlement profits do not increase with an increase in $e$ for values around $\gamma_{g_{1}}^{r r^{\prime}}$ and $\gamma_{g_{2}}^{r r^{\prime}}$, and so their incentives to enter remain unchanged.

When the critical levels of patent strength for which the generic companies are indifferent between entering or not do not exceed $1-\frac{e}{2}$, monopoly results for all $\gamma$ units above $1-e / 2$. In that case, an increase in $e$ still has the same effects as described in Sections 3.3 and 4. It induces settling companies to collude more for values around $\gamma_{g_{1}}^{r r^{\prime}}$ and $\gamma_{g_{2}}^{r r^{\prime}}$ and, thus, enhances generic companies' incentives to enter. 


\section{A2: The Socially Optimal Level of $e$}

Consumer welfare under the rule of reason approach is given by equation (5). Differentiating consumer welfare with respect to $e$ yields

$$
\begin{aligned}
\frac{\partial C W^{r r}}{\partial e}= & \frac{\partial \gamma_{g_{1}}^{r r}}{\partial e}\left(1-\gamma_{g_{1}}^{r r}-\frac{e}{8}\right)\left(C W^{d}-C W^{m}\right)-\frac{\gamma_{g_{1}}^{r r}}{8}\left(C W^{d}-C W^{m}\right) \\
& +\frac{\partial \gamma_{g_{2}}^{r r}}{\partial e}\left(1-\gamma_{g_{2}}^{r r}-\frac{e}{8}\right)(1-\lambda)\left(C W^{t}-C W^{d}\right)-\frac{\gamma_{g_{2}}^{r r}}{8}(1-\lambda)\left(C W^{t}-C W^{d}\right)
\end{aligned}
$$

For the derivation of the consumer welfare maximizing level of $e$ we assume that the companies compete in quantities. The originator companies' inverse demand function is given by $p_{o}=1-q$, and the generic companies' inverse demand function is given by $p_{g}=\alpha-q$, with $0.5 \leq \alpha \leq 1$ and $q=q_{o}+\sum_{i=1}^{2} q_{g_{i}}$. The differentiation factor $\alpha$ reflects the degree to which the generic products are perceived inferior to the original product by consumers. The lower $\alpha$ is, the more demand originator companies receive in comparison to generic companies when charging the same price.

We can substitute

$$
\begin{aligned}
\gamma_{g_{2}}^{r r} & =\frac{(2 \alpha-1)(63-19 \lambda-2 \alpha(27-7 \lambda)) e-216\left(16 f_{g}+(4(1-\alpha) \alpha-1)(1-\lambda)\right)}{216(1-2 \alpha)^{2}(1-\lambda)} \\
\gamma_{g_{1}}^{r r} & =\frac{64\left((1-2 \alpha)^{2}-9 f_{g}\right)+(4(8-5 \alpha) \alpha-11) e}{64(1-2 \alpha)^{2}}
\end{aligned}
$$

$C W^{m}=1 / 8, C W^{d}=((1+\alpha) / 3)^{2}$, and $C W^{t}=3 / 8 \alpha^{2}+3 / 8 \alpha+3 / 32$ into equation (2) and solve it for $e$. This gives us the consumer welfare maximizing level of $e$ :

$$
\begin{aligned}
e^{*}= & {\left[1 7 2 8 \left(486(2 \alpha-1)^{3}(12 \alpha(1+\alpha)-1)-9\left(2 \alpha\left(3383+6484 \alpha+648 \alpha^{2}\right)-721\right) f_{g}\right.\right.} \\
& +\left(-108(2 \alpha-1)^{3}\left(76 \alpha+92 \alpha^{2}-7\right)+(551+2 \alpha(4 \alpha(8253+13618 \alpha))-3729) f_{g}\right) \lambda \\
& \left.\left.+54(2 \alpha-1)^{3}\left(44 \alpha+76 \alpha^{2}-5\right) \lambda^{2}\right)\right] / \\
& {[(2 \alpha-1)(81(65+4 \alpha(2125+\alpha(648 \alpha(23 \alpha-3)-19201)))} \\
& -9(4 \alpha(82869+\alpha(8 \alpha(29079 \alpha-19531)-204777))-22535) \lambda \\
& \left.\left.+16(14 \alpha-19)(94 \alpha-35)\left(44 \alpha+76 \alpha^{2}-5\right) \lambda^{2}\right)\right] .
\end{aligned}
$$

It shows, that $e^{*}$ decreases with generic companies' fixed entry costs $\left(f_{g}\right)$, i.e., with generic companies' incentives to enter. Further, $e^{*}$ increases with the delay of $G_{2}$ 's entry decision $(\lambda)$ and with the degree to which generic products are perceived inferior to original products by consumers $(\alpha)$. This means, the higher $f_{g}$ and $\lambda$ and the lower $\alpha$, the more consumer welfare increases when antitrust evaluations of pay-for-delay settlements under the rule of reason are subject to error. 


\section{A3: Litigation Costs and Expectational Asymmetry}

This appendix analyzes the level of collusion and generic companies' incentives to challenge probabilistic patents under the consideration of (i) litigation and settlement costs $(l \geq \varsigma$ ) and (ii) originator and generic companies misconceiving their respective

likelihoods of success in the litigations $\left(\gamma_{o} \lesseqgtr \gamma, \gamma_{g} \lesseqgtr \gamma\right)$. For simplification we assume in this and the following appendix that only one generic company seeks market entry. The underlying economic intuition of our results remains the same. While we assumed before that companies divide any surplus they generate through settlements compared to litigation by the number of companies involved in the settlement talks, we here compute the Nash Bargaining solutions.

Expected litigation profits of originator and generic companies are

$$
\begin{aligned}
& \pi_{o}^{l}=\gamma_{o} \pi^{m}+\left(1-\gamma_{o}\right) \pi_{o}^{d}-l \\
& \pi_{g}^{l}=\left(1-\gamma_{g}\right) \pi_{g}^{d}-l .
\end{aligned}
$$

The companies' expected profits pursuant to a settlement under the rule of per se illegality (payment $P=0$ ) and under the rule of per se legality (payment $P \geq 0$ ) are

$$
\begin{aligned}
& \pi_{o}=t \pi^{m}+(1-t) \pi_{o}^{d}-P-\varsigma, \\
& \pi_{g}=(1-t) \pi_{g}^{d}+P-\varsigma .
\end{aligned}
$$

The Nash bargaining solution is determined by

$$
\max _{t}\left(\pi_{o}-\pi_{o}^{l}\right)\left(\pi_{g}-\pi_{g}^{l}\right)
$$

As negotiated entry date in the Nash bargaining solution we receive

$$
t=\frac{\gamma_{o}+\gamma_{g}}{2}+\frac{(l-\varsigma)\left(\pi^{m}-\pi_{o}^{d}-\pi_{g}^{d}\right)}{2\left(\pi^{m}-\pi_{o}^{d}\right) \pi_{g}^{d}}+\frac{P\left(\pi^{m}-\pi_{o}^{d}+\pi_{g}^{d}\right)}{2\left(\pi^{m}-\pi_{o}^{d}\right) \pi_{g}^{d}}
$$

In what follows, we analyze the effects of $\gamma_{o}, \gamma_{g}, l$ and $\varsigma$ on the degree of collusion and the generic companies' incentives to enter.

Under the rule of per se legality originator companies are allowed to make payments to generic companies $(P \geq 0)$. Since originator companies can compensate generic companies for any delay in entry compared to litigation, the companies settle on entry terms that maximize their joint profits and negotiate about the division of the generated surplus. They choose $t^{p l}=1$ as generic entry date, independent of their individual perceptions of patent strength and of litigation and settlement costs. Since the degree 
of collusion remains the same, the welfare implications also remain the same.

Under the rule of per se illegality $P$ equals 0 as payments from originator to generic companies are not allowed. Hence, companies settle upon

$$
t^{p i}=\frac{\gamma_{o}+\gamma_{g}}{2}+\frac{(l-\varsigma)\left(\pi^{m}-\pi_{o}^{d}-\pi_{g}^{d}\right)}{2\left(\pi^{m}-\pi_{o}^{d}\right) \pi_{g}^{d}}
$$

Differentiating $t^{p i}$ with respect to $\left(\gamma_{o}+\gamma_{g}\right) / 2$ and $l-\varsigma$ shows that the level of collusion under the rule of per se illegality increases with originator companies being relatively confident and generic companies being relatively unconfident regarding their chances of winning litigation. Further, collusion increases with the difference between litigation and settlement costs.

Generic companies' expected settlement profits are

$$
\pi_{g}^{p i}=\left(1-\frac{\gamma_{o}+\gamma_{g}}{2}-\frac{(l-\varsigma)\left(\pi^{m}-\pi_{o}^{d}-\pi_{g}^{d}\right)}{2\left(\pi^{m}-\pi_{o}^{d}\right) \pi_{g}^{d}}\right) \pi_{g}^{d}-\varsigma .
$$

Thus, the less confident originator companies and the more confident generic companies, the higher are generic companies' incentives to enter. Further, the lower litigation and settlement costs, the higher are generic companies' incentives to enter.

Under the rule of reason originator companies are allowed to make payments to generic companies, so that $P \geq 0$. Settling companies choose entry terms that maximize their expected joint profits and then negotiate about the division of the generated surplus. The companies' expected settlement profits are

$$
\begin{aligned}
& \pi_{o}^{r r}=\frac{t^{r r}-\gamma_{o}+e}{2 e}\left[\gamma_{o} \pi^{m}+\left(1-\gamma_{o}\right) \pi_{o}^{d}\right]+\frac{e-t^{r r}+\gamma_{o}}{2 e}\left[t^{r r} \pi^{m}+\left(1-t^{r r}\right) \pi_{o}^{d}-P\right]-\varsigma \quad \text { and } \\
& \pi_{g}^{r r}=\frac{t^{r r}-\gamma_{g}+e}{2 e}\left(1-\gamma_{g}\right) \pi_{g}^{d}+\frac{e-t^{r r}+\gamma_{g}}{2 e}\left[\left(1-t^{r r}\right) \pi_{g}^{d}+P\right]-\varsigma .
\end{aligned}
$$

Thus, they choose as generic entry dates

$$
t^{r r}=\frac{\gamma_{o}\left(\pi^{m}-\pi_{o}^{d}\right)-\gamma_{g} \pi_{g}^{d}}{\pi^{m}-\pi_{o}^{d}-\pi_{g}^{d}}+\frac{e}{2} .
$$

It follows that the degree of collusion increases with the companies' overconfidence but is independent of litigation and settlement costs.

As under the rule of per se illegality, generic companies' incentives to enter decrease with originator companies' confidence and increase with their own confidence. Further, generic companies' incentives to enter decrease with litigation and settlement costs.

From the analysis we can derive the following policy implications. The higher litigation 
costs relative to settlement costs, the more settling companies collude under the rule of per se illegality, so that in comparison the rule of reason becomes more desirable. If originator companies are overconfident, collusion under the rule of per se illegality and under the rule of reason increases. Under the rule of reason collusion increases by more but through prohibitions of settlements neutral outcomes can still be achieved.

Further, the higher litigation costs relative to settlement costs, the lower are generic companies' incentives to challenge probabilistic patents under the rule of per se illegality and under the rule of reason. It follows, that incentivization as achieved under the rule of reason becomes more desirable. The same applies if originator companies become more overconfident or generic companies less confident. In that case, generic companies' bargaining position is weakened, which derogates their incentives to enter.

\section{A4: Risk Aversion}

Contrary to settlement, litigation poses a risk to companies. Generic companies risk early versus late flow of profits and originator companies risk early versus late loss of monopoly profits. Companies that have more to risk or that are more risk averse tend to accept less favorable settlement terms in order to avoid that settlement fails. Absent any compensation generic companies, which prefer earlier entry to later, might be willing to postpone entry somewhat past the expected entry date under litigation if the postponement is not so protracted that the cost to it in lost profits is more than what is saved in avoided risk. Similarly, originator companies, which prefer later entry to earlier, might be willing to accelerate entry relative to the expected generic entry date under litigation. Because risk aversion has the same effect as an increase in litigation costs we treat the cost of bearing risk as a "risk premium".

In the US, generic companies have not made infringing sales that would give rise to claims for damages or incurred production costs when triggering a patent dispute. Hence, their litigation risk may be rather small. ${ }^{37}$ They only may risk bankruptcy when litigation takes too long. Originator companies face potentially larger consequences if they lose litigation as their profits would drop dramatically. The bargaining strength of companies that bear a higher risk is weakened.

Under the rule of per se illegality $(P=0)$ and under the rule of reason $(P \geq 0)$ the

\footnotetext{
${ }^{37}$ In the EU, generic companies either enter at risk or await a declaratory judgment (after having indicated their intention to enter and received a notice by the originator company that it intends to sue the generic companies for infringement in case of entry). The prerequisites for declaratory judgments differ among EU states.
} 
assumption of $l_{o} \neq l_{g}$ takes the following effects. Expected litigation profits are

$$
\begin{aligned}
& \pi_{o}^{l}=\gamma \pi^{m}+(1-\gamma) \pi_{o}^{d}-l_{o} \\
& \pi_{g}^{l}=(1-\gamma) \pi_{g}^{d}-l_{g}
\end{aligned}
$$

The companies' expected profits pursuant to a settlement are

$$
\begin{aligned}
& \pi_{o}=t \pi^{m}+(1-t) \pi_{o}^{d}-P-\varsigma \\
& \pi_{g}=(1-t) \pi_{g}^{d}+P-\varsigma .
\end{aligned}
$$

As Nash bargaining solution we receive

$$
t=\gamma-\frac{l_{o}}{2\left(\pi^{m}-\pi_{o}^{d}\right)}+\frac{l_{g}}{2 \pi_{g}^{d}}-\frac{\varsigma\left(\pi^{m}-\pi_{o}^{d}-\pi_{g}^{d}\right)}{2\left(\pi^{m}-\pi_{o}^{d}\right) \pi_{g}^{d}}+\frac{P\left(\pi^{m}-\pi_{o}^{d}+\pi_{g}^{d}\right)}{2\left(\pi^{m}-\pi_{o}^{d}\right) \pi_{g}^{d}} .
$$

It follows that under the rule of per se illegality settlements become more procompetitive when originator companies' litigation costs increase, and more anticompetitive when generic companies' litigation costs increase. In line with the results of the previous appendix, collusion under the rule of per se illegality decreases compared to under the rule of reason when the originator companies become more risk averse. This means, the rule of per se illegality becomes more favorable compared to the rule of reason. The opposite is true, and the rule of reason becomes more favorable, when generic companies become more risk averse.

As generic companies' bargaining position is strengthened when originator companies become more risk averse, their incentives to enter improve. Incentivization, as achieved under the rule of reason, becomes less important. Thus, when originator companies become more risk averse the rule of per se illegality prevails. Again, the opposite is true and the rule of reason becomes more favorable when generic companies become more risk averse. 


\section{Appendix B: Proofs}

\section{Proof of Proposition 1.1}

In order to judge whether the rule of reason or the rule of per se illegality is preferable we need to analyze whether consumer welfare is higher under the rule of reason when $e=0$ or when $e>0$. We therefore look at whether a marginal increase in $e$, given $e=0$ in the first place, has positive welfare implications.

Consumer welfare under the rule of reason is

$$
\begin{aligned}
C W^{r r}= & \int_{0}^{\gamma_{g_{2}}^{r r}(e)}\left[\frac{3}{4}\left[\gamma C W^{m}+(1-\gamma)\left[\lambda C W^{d}+(1-\lambda) C W^{t}\right]\right]\right. \\
& \left.+\frac{1}{4}\left[\left(\gamma+\frac{e}{2}\right) C W^{m}+\left(1-\gamma-\frac{e}{2}\right)\left[\lambda C W^{d}+(1-\lambda) C W^{t}\right]\right]\right] d \gamma \\
& +\int_{\gamma_{g_{2}}^{r r}(e)}^{\gamma_{g_{1}}^{r r}(e)}\left[\frac{3}{4}\left[\gamma C W^{m}+(1-\gamma) C W^{d}\right]+\frac{1}{4}\left[\left(\gamma+\frac{e}{2}\right) C W^{m}+\left(1-\gamma-\frac{e}{2}\right) C W^{d}\right]\right] d \gamma \\
& +\int_{\gamma_{g_{1}}^{r r}(e)}^{1} C W^{m} d \gamma \\
= & {\left[\left(1-\frac{e}{8}\right) \gamma_{g_{2}}^{r r}(e)-\frac{\gamma_{g_{2}}^{r r}(e)^{2}}{2}\right](1-\lambda)\left(C W^{t}-C W^{d}\right) } \\
& +\left[\left(1-\frac{e}{8}\right) \gamma_{g_{1}}^{r r}(e)-\frac{\gamma_{g_{1}}^{r r}(e)^{2}}{2}\right]\left(C W^{d}-C W^{m}\right)+C W^{m} .
\end{aligned}
$$

Thus, the effect of a marginal increase in $e$ on consumer welfare is

$$
\begin{aligned}
\frac{\partial C W^{r r}}{\partial e}= & \underbrace{\frac{\partial \gamma_{g_{1}}^{r r}}{\partial e}\left(1-\gamma_{g_{1}}^{r r}-\frac{e}{8}\right)\left(C W^{d}-C W^{m}\right)}_{\text {Incentive Effect-G }}-\underbrace{\frac{\gamma_{g_{1}}^{r r}}{8}\left(C W^{d}-C W^{m}\right)}_{\text {Entry Delay Effect-G }} \\
& +\underbrace{\frac{\partial \gamma_{g_{2}}^{r r}}{\partial e}\left(1-\gamma_{g_{2}}^{r r}-\frac{e}{8}\right)(1-\lambda)\left(C W^{t}-C W^{d}\right)}_{\text {Incentive Effect }-G_{2}}-\underbrace{\frac{\gamma_{g_{2}}^{r r}}{8}(1-\lambda)\left(C W^{t}-C W^{d}\right)}_{\text {Entry Delay Effect }-G_{2}} .
\end{aligned}
$$

Equation (6) shows, when $e$ (the imprecision of antitrust enforcement under the rule of reason) increases, settling companies agree upon later generic entry dates than under the rule of per se illegality, i.e., they collude more. Under each settlement competition is restrained, which leads to consumer welfare losses. As shown by equation (6), for all values of patent strength for which settlements would also result absent an increase in $e$, that is for all intramarginal $\gamma_{g_{1}}^{r r}$ - and $\gamma_{g_{2}}^{r r}$-units, consumer welfare decreases by $1 / 8\left(C W^{d}-C W^{m}\right)$ and $1 / 8(1-\lambda)\left(C W^{t}-C W^{d}\right)$, respectively.

Through collusion the companies' expected settlement profits increase and with it the critical levels of patent strength for which the generic companies are indifferent between entering or not $\left(\gamma_{g_{1}}^{r r}\right.$ and $\left.\gamma_{g_{2}}^{r r}\right)$. The generic companies find it profitable to also contest patents of higher strength. This affects consumer welfare positively 
when collusion under the additional settlements is limited. As shown by equation (6), a marginal increase in $e$ leads to an increase in $\gamma_{g_{1}}^{r r}$ by $\partial \gamma_{g_{1}}^{r r} / \partial e$, meaning first generic companies enter for additional $\partial \gamma_{g_{1}}^{r r} / \partial e$ units. For each of these units consumer welfare increases by $\left(1-\gamma_{g_{1}}^{r r}-e / 8\right)\left(C W^{d}-C W^{m}\right)$. A marginal increase in $e$ also leads to an increase in $\gamma_{g_{2}}^{r r}$ by $\partial \gamma_{g_{2}}^{r r} / \partial e$. Thus, second generic companies enter for additional $\partial \gamma_{g_{2}}^{r r} / \partial e$ units. For each of these units consumer welfare increases by $\left(1-\gamma_{g_{2}}^{r r}-e / 8\right)(1-\lambda)\left(C W^{t}-C W^{d}\right)$.

Thus, the imperfection of antitrust enforcement under the rule of reason has two countervailing effects on consumer welfare. It induces settling parties to delay entry, affecting consumer welfare negatively. At the same time, it enhances generic companies' incentives to challenge probabilistic patents, affecting consumer welfare positively.

Next, we analyze under which conditions the negative entry delay effect of a marginal increase in $e$ is outweighed by the positive incentive effect, implying that the rule of reason outperforms the rule of per se illegality. This is the case when the marginal effect of an increase in $e$ on consumer welfare is positive, given $e=0$ in the first place. Setting the first line of equation (6) equal to zero, inserting $e=0$, and solving for $\gamma_{g_{1}}^{r r}$ yields

$$
\gamma_{g_{1}}^{r r^{\prime}} \equiv \frac{\Delta_{1}}{\Delta_{1}+2 \pi_{g}^{d}},
$$

where $\Delta_{1}=\pi^{m}-\pi_{o}^{d}-\pi_{g}^{d}$. Accordingly, setting the second line of equation (6) equal to zero, inserting $e=0$, and solving for $\gamma_{g_{2}}^{r r}$ yields

$$
\gamma_{g_{2}}^{r r^{\prime}} \equiv \frac{\Delta_{2}}{\Delta_{2}+3(1-\lambda) \pi_{g}^{t}}
$$

where $\Delta_{2}=\pi^{m}-\lambda\left(\pi_{o}^{d}+\pi_{g}^{d}\right)-(1-\lambda)\left(\pi_{o}^{t}+2 \pi_{g}^{t}\right)$. It follows that consumer welfare is higher under the rule of reason than under the rule of per se illegality when $\gamma_{g_{1}}^{r r}<\gamma_{g_{1}}^{r r^{\prime}}$ and $\gamma_{g_{2}}^{r r}<\gamma_{g_{2}}^{r r^{\prime}}$.

We can further specify these conditions by substituting in $\gamma_{g_{1}}^{r r}=1-f_{g} / \pi_{g}^{d}$ and $\gamma_{g_{2}}^{r r}=1-f_{g} /(1-\lambda) \pi_{g}^{t}$. We obtain that the rule of reason yields higher consumer welfare than the rule of per se illegality if

$$
f_{g_{1}}>\frac{2 \pi_{g}^{d^{2}}}{2 \pi_{g}^{d}+\Delta_{1}} \quad \text { and } f_{g_{2}}>\frac{3\left((1-\lambda) \pi_{g}^{t}\right)^{2}}{(1-\lambda) \pi_{g}^{t}+\Delta_{2}}
$$




\section{Proof of Proposition 1.2}

The proof that the HWA provisions have anticompetitive effects proceeds in two steps. We first show that the HWA provisions alleviate second generic companies' incentives to enter $\left(\gamma_{g_{2}}^{h w a}<\gamma_{g_{2}}\right)$. We then show that the HWA provisions do not provide first generic companies additional incentives to enter $\left(\gamma_{g_{1}}^{h w a} \equiv \gamma_{g_{1}}\right)$.

When the HWA provisions apply, $G_{2}$ 's expected entry date under litigation postpones to $t_{g_{2}}^{l \mid h w a}=\gamma+(1-\gamma)(\lambda+\nu)$, where $\nu$ denotes the 180 days marketing exclusivity period during which the FDA may not approve any subsequent ANDA. When $G_{2}$ wants to enter and $G_{1}$ settled with $O$ before, $G_{2}$ has to file an ANDA (para. IV), whereupon it can be sued by $O$ for infringement. With probability $\gamma G_{2}$ would then loose litigation and enter at time $t=1$, whereas with probability $(1-\gamma)$ it would win litigation, trigger the 180 days exclusivity period at time $t=\lambda$, and enter at time $t=\lambda+\nu$.

Because $G_{2}$ 's expected entry date under litigation postpones, it has less negotiation power and therefore settles with $O$ on later entry dates. Under the rule of reason $O$ and $G_{2}$ agree upon $t_{g_{2}}^{r r \mid h w a}=\gamma+e / 2+(1-\gamma-e / 2)(\lambda+\nu)$, whereas under the rule of per se illegality they agree upon $t_{g_{2}}^{\text {pilhwa }}=\gamma+(1-\gamma)(\lambda+\nu)$.

Under the rule of reason not only $G_{2}$ 's entry date postpones, the companies also generate a lower surplus when $G_{2}$ finds it profitable to enter:

$$
s_{1}^{r r \mid h w a}=\frac{e}{2}\left[\pi^{m}-(\lambda+\nu)\left(\pi_{o}^{d}+\pi_{g}^{d}\right)-(1-\lambda-\nu)\left(\pi_{o}^{t}+2 \pi_{g}^{t}\right)\right] .
$$

Because $G_{2}$ 's entry date postpones and a lower settlement surplus is generated when it enters, its incentives to enter deplete. That is, the critical level of patent strength, for which $G_{2}$ is indifferent between entering or not, decreases to

$$
\gamma_{g_{2}}^{r r \mid h w a}=1-\frac{f_{g}-\frac{s_{1}^{r r \mid h w a}}{12}}{(1-\lambda-\nu) \pi_{g}^{t}}<\gamma_{g_{2}}^{r r} .
$$

Under the rule of per se illegality, settling companies still generate no surplus, i.e., $s^{p i \mid h w a} \equiv s^{p i}=0$. But since $G_{2}$ 's entry date postpones, the critical level of patent strength, for which $G_{2}$ is indifferent between entering or not, decreases to

$$
\gamma_{g_{2}}^{p i \mid h w a}=1-\frac{f_{g}-\frac{s^{p i \mid h w a}}{3}}{(1-\lambda-\nu) \pi_{g}^{t}}<\gamma_{g_{2}}^{p i} .
$$

Next, we analyze whether the HWA provisions provide $G_{1}$ incentives to challenge patents that it would not challenge otherwise, i.e., patents of strength $\gamma \in\left(\gamma_{g_{1}}, 1\right]$. This would be the case if $G_{1}$ 's expected settlement profits increased due to the HWA 
provisions for patents of strength $\gamma \in\left(\gamma_{g_{1}}, 1\right]$. Indeed, $G_{1}$ 's expected settlement increase due to the HWA provisions for patents of strength $\gamma \in\left(0, \gamma_{g_{2}}\right]$, as for these values competition between $G_{1}$ and $G_{2}$ is restrained as either $G_{2}$ enters at a later point in time (if $\gamma \in\left[0, \gamma_{g_{2}}^{h w a}\right]$ ), or $G_{2}$ does not enter at all (if $\gamma \in\left(\gamma_{g_{2}}^{h w a}, \gamma_{g_{2}}\right]$ ). However, since $\gamma_{g_{2}}<\gamma_{g_{1}} G_{1}$ 's expected settlement do not increase for patents of strength $\gamma \in\left(\gamma_{g_{1}}, 1\right]$ as for these patents $G_{2}$ would also, even absent the HWA provisions, not enter. An exclusivity right that restricts competitions between $G_{1}$ and $G_{2}$ is effectless here, as competition would not arise anyway. Therefore, $G_{1}$ 's incentives to challenge additional patents of strength $\gamma \in\left(\gamma_{g_{1}}, 1\right]$ do not improve, that is, $\gamma_{g_{1}}^{h w a} \equiv \gamma_{g_{1}}$.

Note that under the rule of per se legality basically the same mechanisms apply. But an increase in generic companies' incentives to enter would not have a positive effect on consumer welfare anyway as collusion under this rule is maximal. 


\section{References}

[1] Addanki, Sumanth, and Alan J. Daskin (2008), "Patent Settlement Agreements," book chapter 85, published in: Issues in Competition Law and Policy, American Bar Association.

[2] Arrow, Kenneth J. (1961), "Economic Welfare and the Allocation of Resources for Invention," in: Nelson, R. (ed.): The Rate and Direction of Inventive Activity: Economic and Social Factors, Princeton University Press, 609-626.

[3] Balto, David (2004), "Bringing Clarity to the Patent Settlement Debate: Judge Posner's Asahi Decision," Biotechnology Law Report, 23(2), 168-171.

[4] Blair, Roger D., and Thomas F. Cotter (2002), "Are Settlements of Patent Disputes Illegal Per Se?," The Antitrust Bulletin, 47, 491-539.

[5] Bulow, Jeremy (2003), "The Gaming of Pharmaceutical Patents," Stanford Research Paper No. 1804.

[6] Crane, Daniel A. (2002), "Exit Payments in Settlement of Patent Infringement Lawsuits: Antitrust Rules and Economic Implications," Florida Law Review, 54, 747-798.

[7] European Commission, Competition DG, (2008), "Pharmaceutical Sector Inquiry-Preliminary Report," DG Competition Staff Working Paper, available online at: http://ec.europa.eu/competition/sectors/pharmaceuticals/inquiry/ preliminary_report.pdf.

[8] European Commission, Competition DG, (2009), "Pharmaceutical Sector Inquiry -Final Report," available online at: http://ec.europa.eu/competition/ sectors/pharmaceuticals/inquiry/staff_working_paper_part1.pdf.

[9] European Commission, Competition DG, (2010), "1 ${ }^{\text {st }}$ Report on the Monitoring of Patent Settlements," available online at: http://ec.europa.eu/competition/ sectors/pharmaceuticals/inquiry/patent_settlements_report1.pdf.

[10] Farrell, Joseph, and Robert P. Merges (2004), "Incentives to Challenge and Defend Patents: Why Litigation Won't Reliably Fix Patent Office Errors and Why Administrative Patent Review Might Help," Boalt Working Papers in Public Law.

[11] Federal Trade Commission (2002), "Generic Drug Entry Prior to Patent Expiration," available at http://www.ftc.gov/os/2002/07/genericdrugstudy.pdf. 
[12] Harhoff, Dietmar, Frederic M. Scherer, and Katrin Vopel (2003), "Citations, Family Size, Opposition and the Value of Patent Rights," Research Policy, 32, 13431363.

[13] Hemphill, C. Scott (2006), "Paying for Delay: Pharmaceutical Patent Settlement As a Regulatory Design Problem," New York University Law Review 1553.

[14] Hemphill, C. Scott (2009), "An Aggregate Approach to Antitrust: Using New Data and Rulemaking to Preserve Drug Competition," Columbia Law Review.

[15] Hemphill, C. Scott, and Mark A. Lemley (2011), "Earning Exclusivity: Generic Drug Incentives and the Hatch-Waxman Act," Antitrust Law Journal, forthcoming.

[16] Hovenkamp, Herbert, Mark Janis, and Mark A. Lemley (2003), "Anticompetitive Settlements of Intellectual Property Disputes," Minnesota Law Review, 87, 17191766.

[17] Langenfeld, James, and Wenqing Li (2003), "Intellectual Property and Agreements to Settle Patent Disputes: The Case of Settlement Agreements with Payments from Branded to Generic Drug Manufacturers," Antitrust Law Journal, 70(3), $777-818$.

[18] Leffler, Keith, and Cristofer Leffler (2004), "Efficiency Trade-Offs in Patent Litigation Settlements? Analysis Gone Astray," University of San Francisco Law Review, 39, 33-56.

[19] Lemley, Mark A. (2001), "Rational Ignorance at the Patent Office," Northwestern University Law Review, 95(4).

[20] Lemley, Marc A., and Carl Shapiro (2005), "Probabilistic Patents," Journal of Economic Perspective, 19(2), 75-98.

[21] O'Rourke, Maureen, and Joseph F. Brodley (2003), "Antitrust Implications of Patent Settlements: An Incentives Modifying Approach," Minnesota Law Review, 87, 101-123.

[22] Salinger, Michael A., Pauline M. Ippolito, and Joel L. Schrag (2007), "Economics at the FTC: Pharmaceutical Patent Dispute Settlements and Behavioral Economics," Review of Industrial Organization, 31(2), 85-105.

[23] Schildkraut (2004), "Patent-Splitting Settlements and the Reverse Payment Fallacy," Antitrust Law Journal, 71(3), 1033-1068. 
[24] Shapiro, Carl (2003), "Antitrust Limits to Patent Settlements," The RAND Journal of Economics, 34(2), 391-411.

[25] United States Patent and Trademark Office (2009), "Performance and Accountability Report," available at http://www.uspto.gov/about/stratplan/ ar/index.jsp.

[26] Willig, Robert D., and John P. Bigelow (2004), "Antitrust Policy Toward Agreements that Settle Patent Litigation," The Antitrust Bulletin, 49(3), 655-698. 